\title{
Exosomes Engineering and Their Roles as Therapy Delivery Tools, Therapeutic Targets, and Biomarkers
}

\author{
Nika Kučuk ${ }^{1}$, Mateja Primožič ${ }^{1}$, Željko Knez ${ }^{1,2}$ (D) and Maja Leitgeb ${ }^{1,2, *(D)}$ \\ 1 Faculty of Chemistry and Chemical Engineering, University of Maribor, Smetanova 17, \\ 2000 Maribor, Slovenia; nika.kucuk@um.si (N.K.); mateja.primozic@um.si (M.P.); zeljko.knez@um.si (Ž.K.) \\ 2 Faculty of Medicine, University of Maribor, Taborska Ulica 8, 2000 Maribor, Slovenia \\ * Correspondence: maja.leitgeb@um.si; Tel.: +386-2-2294-462
}

Citation: Kučuk, N.; Primožič, M.; Knez, Ž.; Leitgeb, M. Exosomes Engineering and Their Roles as Therapy Delivery Tools, Therapeutic Targets, and Biomarkers. Int. J. Mol. Sci. 2021, 22, 9543. https://doi.org/ $10.3390 /$ ijms 22179543

Academic Editors: Catarina

Pinto Reis and Maria Manuela Gaspar

Received: 2 August 2021

Accepted: 30 August 2021

Published: 2 September 2021

Publisher's Note: MDPI stays neutral with regard to jurisdictional claims in published maps and institutional affiliations.

Copyright: (c) 2021 by the authors. Licensee MDPI, Basel, Switzerland. This article is an open access article distributed under the terms and conditions of the Creative Commons Attribution (CC BY) license (https:// creativecommons.org/licenses/by/ $4.0 /)$.

\begin{abstract}
Exosomes are becoming increasingly important therapeutic biomaterials for use in a variety of therapeutic applications due to their unique characteristics, especially due to the ineffectiveness and cytotoxicity of some existing therapies and synthetic therapeutic nanocarriers. They are highly promising as carriers of drugs, genes, and other therapeutic agents that can be incorporated into their interior or onto their surface through various modification techniques to improve their targeting abilities. In addition, they are biocompatible, safe, and stable. The review focuses on different types of exosomes and methods of their preparation, including the incorporation of different kinds of cargo, especially for drug delivery purposes. In particular, their importance and effectiveness as delivery vehicles of various therapeutic agents for a variety of therapeutic applications, including different diseases and disorders such as cancer treatment, cardiovascular and neurodegenerative diseases, are emphasized. Administration routes of exosomes into the body are also included. A novelty in the article is the emphasis on global companies that are already successfully developing and testing such therapeutic biomaterials, with a focus on the most influential ones. Moreover, a comparison of the advantages and disadvantages of the various methods of exosome production is summarized for the first time.
\end{abstract}

Keywords: exosomes; therapeutic biomaterials; cargo incorporation; therapeutic applications; drug delivery

\section{Introduction}

Various diseases and disorders, as well as conventional drug dosage forms, have led to the development of improved treatment pathways, one of which is drug delivery using a variety of nanocarriers [1,2]. Drug delivery is defined as the introduction of therapeutic drugs or active compounds into the human body through various administration routes, thereby achieving the desired therapeutic effect, improving efficiency and safety, as well as controlling the time and amount of drug release at the target location [2,3]. Such methods have the ability to improve the chemical stability of active compounds and improve their solubility. A smaller amount of drugs can be used and thus reduce any possible side effects and toxicity that may be present when using conventional therapies [3,4]. Conventional drug administration has some drawbacks, such as repeated drug dosing, where it is also difficult to achieve a specific target with a predicted concentration, uncontrolled drug release, and low bioavailability. Therefore, conventional drug administration has been used less and less recently, and a growing number of approaches have been developed to form different nanoparticles as nanocarriers suitable for drug delivery due to the programmed release of drugs to specific target locations [1,4].

Drug nanocarriers must ensure maximum efficacy, and therefore they need to be properly constructed and must have certain properties, such as biodegradability, nonimmunogenicity, stability, ease of design, and delivery of cargo only to specific target cells or tissues [5]. They typically do not exceed a size of $100 \mathrm{~nm}$ and are non-toxic as 
they are made from biocompatible components. They have the ability to be selective and deliver the drug appropriately to diseased cells and not to healthy ones. Examples of these nanocarriers are liposomes, niosomes, micelles, dendrimers, and nanofibers [6], as well as exosomes [7].

Exosomes have become highly important nanocarriers due to their biocompatibility and safety [8]. In the past, scientists were convinced that exosomes were only cell debris without any important function, and their significance has only been discovered in the last two decades [9]. Exosomes are highly biostable, even in long-distance cell-to-cell communication [7]. They are able to deliver their cargo to recipient cells owing to the fact that the surface of exosomes has a specific molecular composition [10]. Additionally, they have the ability to stay unaltered through the digestive system, including when exposed to different digestive enzymes and other body fluids [8]. Therefore, exosomes are suitable carriers for the delivery of different biologically active compounds and other components that are easily degraded, as they can be incorporated into exosomes [11,12].

Exosomes are considered to be nanoparticles due to their size, ranging from 30-100 nm, and some of their properties, which are similar to nanoparticles, such as passive targeting and increased permeability and retention effects [13]. There are numerous types of cells that secrete these nanovesicles. Their important function involves intercellular communication by transferring different molecules, such as proteins, lipids, nucleic acids (DNAs and RNAs), and metabolites. The cargo of exosomes produced from different cells varies greatly $[7,14,15]$. Exosomes are produced from multivesicular bodies, which are considered to be formed by the budding of the plasma membrane, and when fusion between multivesicular bodies and the plasma membrane occurs, exosomes are secreted from the cells into the extracellular environment [7,15-17]. Exosomes serve as delivery vehicles of incorporated drugs and other active compounds, which can act synergistically with naturally occurring components in exosomes [18].

Not all the components present in naturally isolated exosomes are necessary for specific drug delivery, and therefore the use of synthetic therapeutic biomaterials, such as modified and synthetic exosomes, may be better for efficient drug delivery, as they are pure and precisely characterized nanocarriers $[18,19]$.

Modified naturally isolated exosomes and synthetic exosomes that are completely artificial and produced in the laboratory are considered to be synthetic therapeutic biomaterials. Modified exosomes can be altered before their isolation with pre-isolation modifications or after their isolation with post-isolation modifications. Synthetic exosomes can also be produced through two different methodologies. They can be produced through a cell-based approach from larger substrates, which are then reduced to smaller units, and thus vesicles can be formed, or through a lipid membrane bilayer formation approach where individual molecules are used as substrates that assemble into complex structures [18,20].

Exosomes can be used for a variety of purposes, namely as cargo delivery vehicles, biomarkers, and therapeutic agents for the identification of various diseases, and in the development of new vaccines, mainly for cancer treatment [21-23].

This review article presents the growing importance of therapeutic biomaterialsexosomes in a variety of biomedical applications, primarily for use as delivery vehicles for drugs and other therapeutic agents. The division of exosomes and their isolation, modification, and production techniques are briefly explained. The article also includes a short schematic overview of the incorporation of cargo into exosomes, divided by hydrophobicity or hydrophilicity, which has not been presented in detail so far. In contrast, in other review articles the division was made mainly according to the exosomes' source or incorporation method. For the first time, the preparation of exosomes on an industrial scale, where commercial companies that have already successfully established various exosome platforms and are already producing exosomes for therapeutic purposes, is presented. The most influential companies and their exosome products are also described, with an emphasis on their intended use. Special attention is also given to possible administration routes of therapeutic biomaterials. A comparison of the advantages and disadvantages 
of the various methods of exosome production and preparation are also given for the first time.

\section{Exosomes}

Exosomes are classified as extracellular vesicles (EVs), among which they are the smallest. EVs also include microvesicles (50-1000 nm) and apoptotic bodies (500-2000 nm) [14], as shown in Figure 1. They are classified according to their size, intracellular origin [24], and biophysiological properties [25].

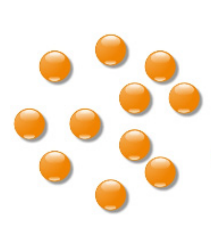

$30-100 \mathrm{~nm}$
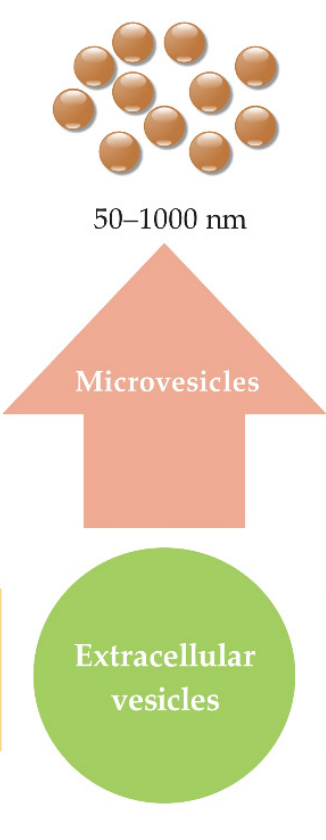

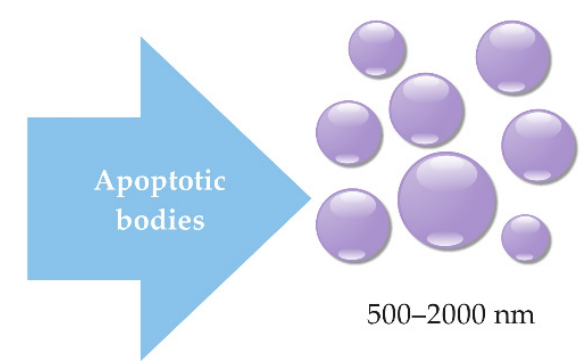

Figure 1. Classification of extracellular vesicles according to their size into exosomes (size diameter around 30-100 nm), microvesicles (size diameter around 50-1000 nm), and apoptotic bodies (size diameter around 500-2000 nm; summarized from $[14,16,25,26])$.

Microvesicles, also known as ectosomes [27], are formed through the process of membrane budding, followed by fission of the vesicle from the surface of the cell [25]. Therefore, microvesicles contain proteins present in the plasma membrane and also cytosolic proteins, nucleic acids, and different metabolites [27].

Vesicles released from dying cells by a process called disassembly of apoptotic cells during apoptosis (programmed cell death) are apoptotic bodies. Apoptotic bodies are the largest extracellular vesicles and contain the remains of dying cells, including the plasma membrane, as well as nuclear and cytoplasmic material. They can also transmit their content through cell-to-cell communication [25,26,28,29].

As mentioned before, exosomes are the smallest among extracellular vesicles. Zhang et al. [30] classified exosomes based on asymmetric flow field-flow fractionation technology. They discovered two subpopulations of exosomes and named them large exosomes $(90-120 \mathrm{~nm})$ and small exosomes $(60-80 \mathrm{~nm})$, as well as specific non-membranous nanoparticles named exomeres $(\sim 35 \mathrm{~nm})$.

Cells can secrete specific subpopulations of exosomes with a certain size and composition of proteins and nucleic acids, which strongly affects recipient cells [31].

The composition of exosomes coincides with the composition of the cell from which they are secreted; they also have the same regulated sorting mechanism [32]. The interior and surface of exosomes contain various bioactive compounds, including proteins, enzymes, receptors, growth factors, transcription factors, nucleic acids (mRNA, miRNA, DNA), lipids, and other metabolites [32-34]. The lipid composition includes cholesterol, phosphatidylserine, sphingomyelin, and saturated fatty acids. Among proteins, they con- 
tain the cytoplasmic, plasma, intracellular proteins, and nucleoprotein [35]. On the other hand, the membrane of exosomes normally contains ceramide, diacylglycerol, cholesterol and various transmembrane (surface) proteins, such as tetraspanins (CD9, CD63, CD81, CD82), fusion and transferring proteins (Rab2, Rab7, flotillin and annexin), lysosomeassociated membrane glycoproteins (LAMP1 and LAMP2), heat shock proteins (Hsc70 and Hsc90), the tumor-sensitive gene 101 (Tsg101), cytoskeleton proteins (actin, myosin and tubulin), integrins, transferrin receptors, and MHC class I and II molecules [16,32,36-39].

Exosomes have promising potential as drug and gene delivery vehicles, and can be used in tissue regeneration, immunomodulation, and as disease identifiers [15,18]. They are also crucial in the coagulation process, intercellular signaling, and cell waste management [40].

Recently, a lot of attention has been paid to artificial exosomes, which are considered to be better potential therapeutic biomaterials than natural exosomes. Exosomes can be classified according to their origin, and therefore divided into natural, modified, and synthetic exosomes (Figure 2) [18].
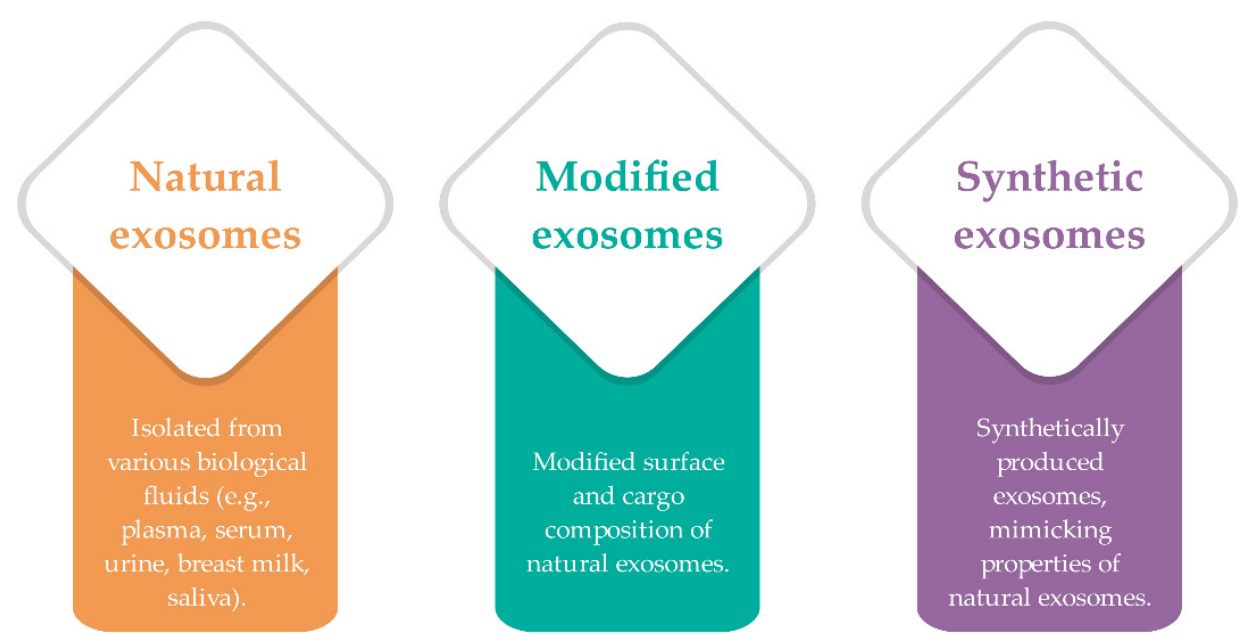

Figure 2. Schematic representation of exosomes classification according to their origin-natural (isolated from various biological fluids), modified (natural produced and modified for specific purposes), and synthetic exosomes (they mimic properties of natural exosomes; summarized from $[16,18,20]$ ).

\subsection{Natural Exosomes}

Exosomes are natural nanomaterials [41] secreted from different types of cells, including epithelial cells, endothelial cells, mesenchymal stem cells, macrophages, dendritic cells, tumor cells, neurons, oligodendrocytes, reticulocytes, mast cells, platelets and cancer cells, B and T cells, and astrocytes by exocytosis [16,37,40,42]. They are present in most body fluids, including plasma [43], serum [44,45], urine [46,47], breast milk [48-50], semen [51,52], saliva [53,54], nasal secretion [37], lymph [16], amniotic fluid [55,56], ascites [57,58], cerebrospinal fluid [59-61], etc. Exosomes are potential natural therapeutics, due to their biocompatibility [7].

\subsubsection{Exosomes Isolation Techniques}

Various methods (Figure 3) have been developed to successfully isolate exosomes from different sources. The most commonly used technique for isolating exosomes is ultracentrifugation, which provides high amounts of isolated exosomes $[11,62,63]$. This technique is based on the difference in density and particle size and is a simple and costeffective method $[8,64]$. It involves differential ultracentrifugation and density-gradient ultracentrifugation [16]. Ultrafiltration and size-exclusion chromatography are isolation methods based on the separation of biomolecules according to their size $[11,62,64,65]$. Methods based on interactions between antibodies and proteins on the surface of exosomes for exosome isolation are immunocapture techniques [16,21,62]. Another method for 
isolation of exosomes is polymer precipitation [66], an easy and simple method [62] based on changing their solubility [16]. Microfluidic technologies are also being used to isolate and purify exosomes. These are improved methods with high purity and sensitivity $[16,62,64]$.

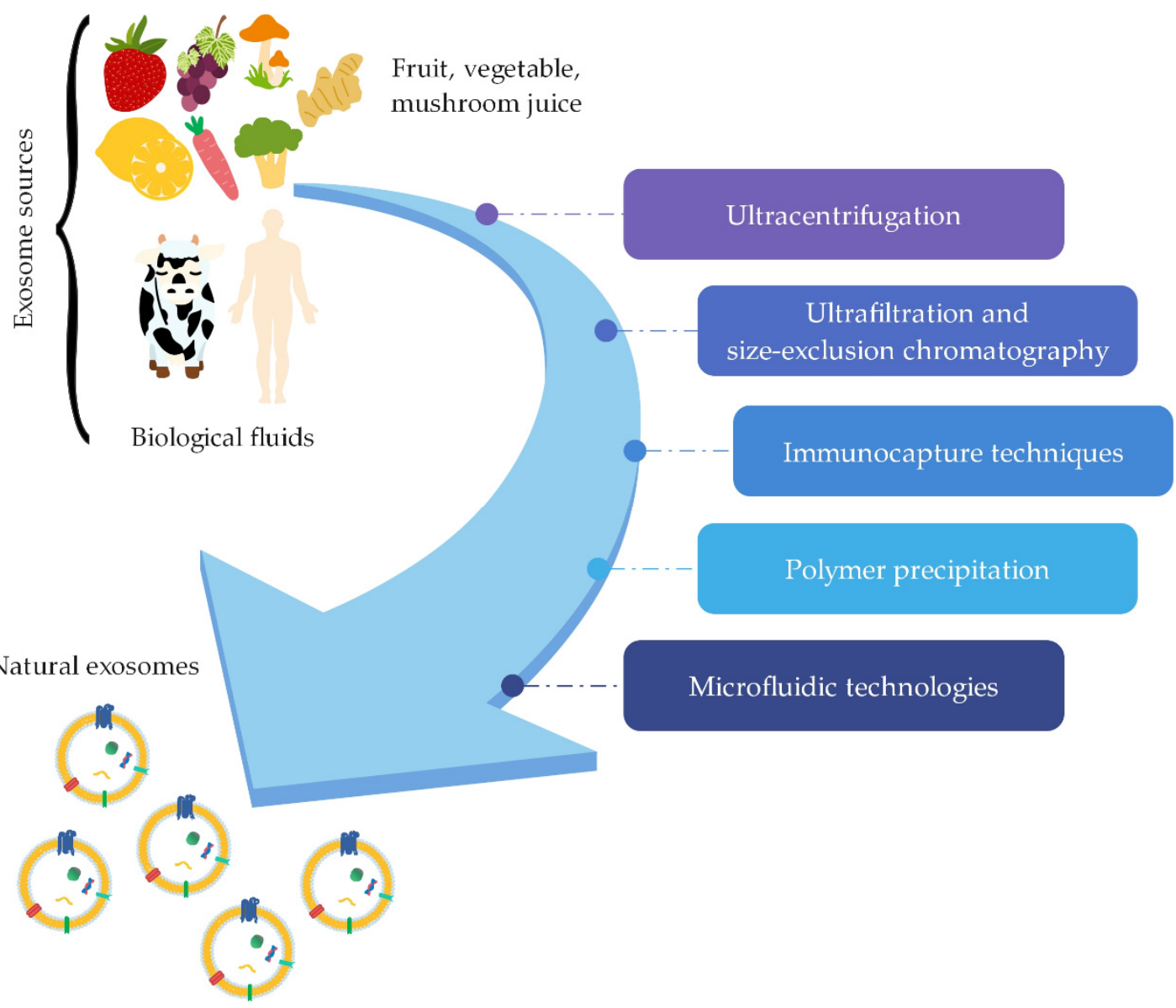

Figure 3. Various methods (ultracentrifugation, ultrafiltration and size-exclusion chromatography, immunocapture techniques, polymer precipitation, and microfluidic technologies) for natural exosomes isolation from different sources (e.g., biological fluids and fruit, vegetable, and mushroom juices; summarized from $[8,11,16,62])$.

\subsubsection{Natural Exosome-like Nanoparticles}

Natural exosome-like nanoparticles can be classified into exosomes derived from animals and exosomes derived from plants [11]. Animal exosomes are produced primarily from immune cells (lymphocytes, red blood cells, platelets, dendritic cells, tumor cells) and are present in various biofluids (urine, milk, plasma). The most researched exosomes of animal origin are exosomes isolated from bovine milk [16]. Recently, increasing attention is being paid to exosome-like nanoparticles derived from plants (plant exosomes) [8], with a comparable structure to animal and human exosomes [11]. However, they differ from these in the composition of proteins, lipids, and RNA [67].

Exosome-like nanoparticles isolated from a variety of plant sources have the potential to be used as therapeutic drug delivery vehicles for the treatment of certain diseases $[67,68]$. Edible plant exosomes derived from ginger, lemon, grapefruit, grape, broccoli, and carrot would be suitable for the treatment of inflammatory diseases due to their anti-inflammatory properties [69-73]. Perut et al. [74] isolated and purified exosomes from strawberries that had a similar morphology to mammalian exosomes. Exosomes derived from strawberry juice have been found to prevent oxidative stress and are non-toxic.

Exosome-like nanoparticles are also naturally present in mushrooms and contain lipids, proteins, and RNA. Liu et al. [75] successfully isolated exosomes from different 
edible mushrooms (Hypsizygus tessellatus, Agaricus bisporus, Pleurotus eryngii, Lentinula edodes, and Pleurotus ostreatus) by sequential centrifugation. Among these, exosomes isolated from shiitake mushroom (L. edodes) showed strong anti-inflammatory activity and potential for the treatment of fulminant hepatic failure (FHF).

The most commonly used isolation technique for isolating animal-derived and plantderived exosomes is differential ultracentrifugation [8]. Other techniques used to isolate the aforementioned exosomes are ultrafiltration, size exclusion chromatography, precipitation, and microfluidic technologies [67]. After isolation, various biologically active components can be incorporated into them and used as drug delivery vehicles [8].

\subsection{Modified Exosomes}

Naturally produced exosomes can be modified for specific therapeutic purposes [20], including the incorporation of drugs and other therapeutic agents, as well as changing the surface charge for faster drug uptake [18].

Exosomes produced from various natural sources, such as different fruit and vegetable juices and mammalian biological fluids, have already been modified in numerous studies in order to verify their potential for biomedical applications.

Exosomes can be modified in two different ways, by interior modification, where the structure of the cargo within the exosome is modified, and surface modification, where the structure of the outer surface of the exosome is modified.

\subsubsection{Interior Modifications}

Interior modifications include methods for incorporating therapeutic agents into the interior of naturally derived exosomes. These methods can ensure different efficiency and stability of the incorporated cargo [7]. They are further divided into pre-isolation (Figure 4) and post-isolation modification methods (Figure 5) for incorporation of cargo, depending on whether the modifications are performed before or after exosome isolation.

\section{Pre-isolation modification methods}
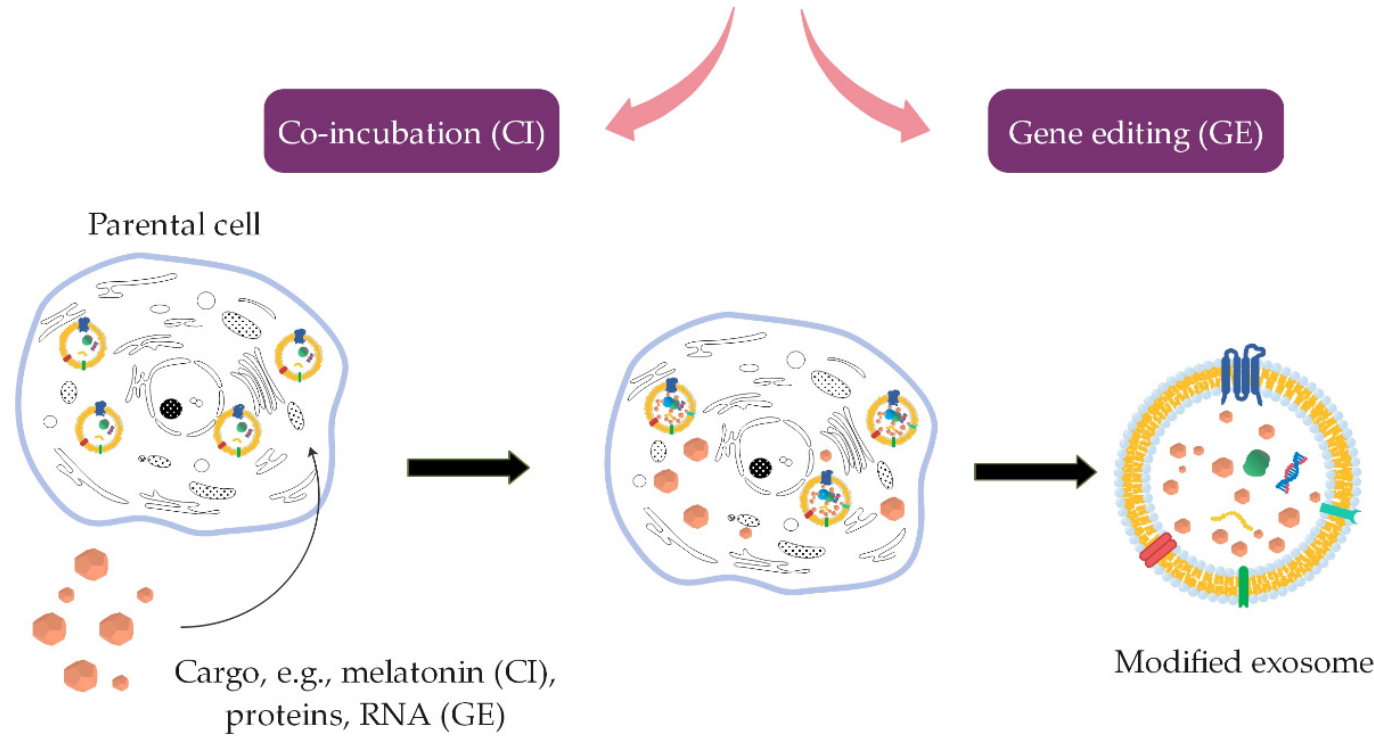

Modified exosome

Figure 4. Principle of pre-isolation exosomes modification methods (co-incubation and gene editing (intended for the incorporation of RNA and proteins), where the modification of exosomes is performed before isolating exosomes from parental cells (summarized from $[7,11,76])$. 


\section{Pre-Isolation Modification Methods}

In pre-isolation modification methods, modification is performed prior to exosome isolation from cells (Figure 4).

The parental cells are modified by the method of incubation with the desired drug, whereby this drug is then encapsulated into the cells. From these modified cells, exosomes that already contain the incorporated desired drug are then secreted and isolated $[7,15,16,77]$. This is a relatively simple method, but it is not possible to provide control over loading efficiency [78]. This method was performed on mesenchymal stromal cells into which melatonin was incorporated. These cells then produced exosomes containing melatonin [76]. Another method is gene editing, where genetic modification of parental cells is used to incorporate therapeutic cargo such as RNA and proteins that cannot be directly incorporated into exosomes [11].

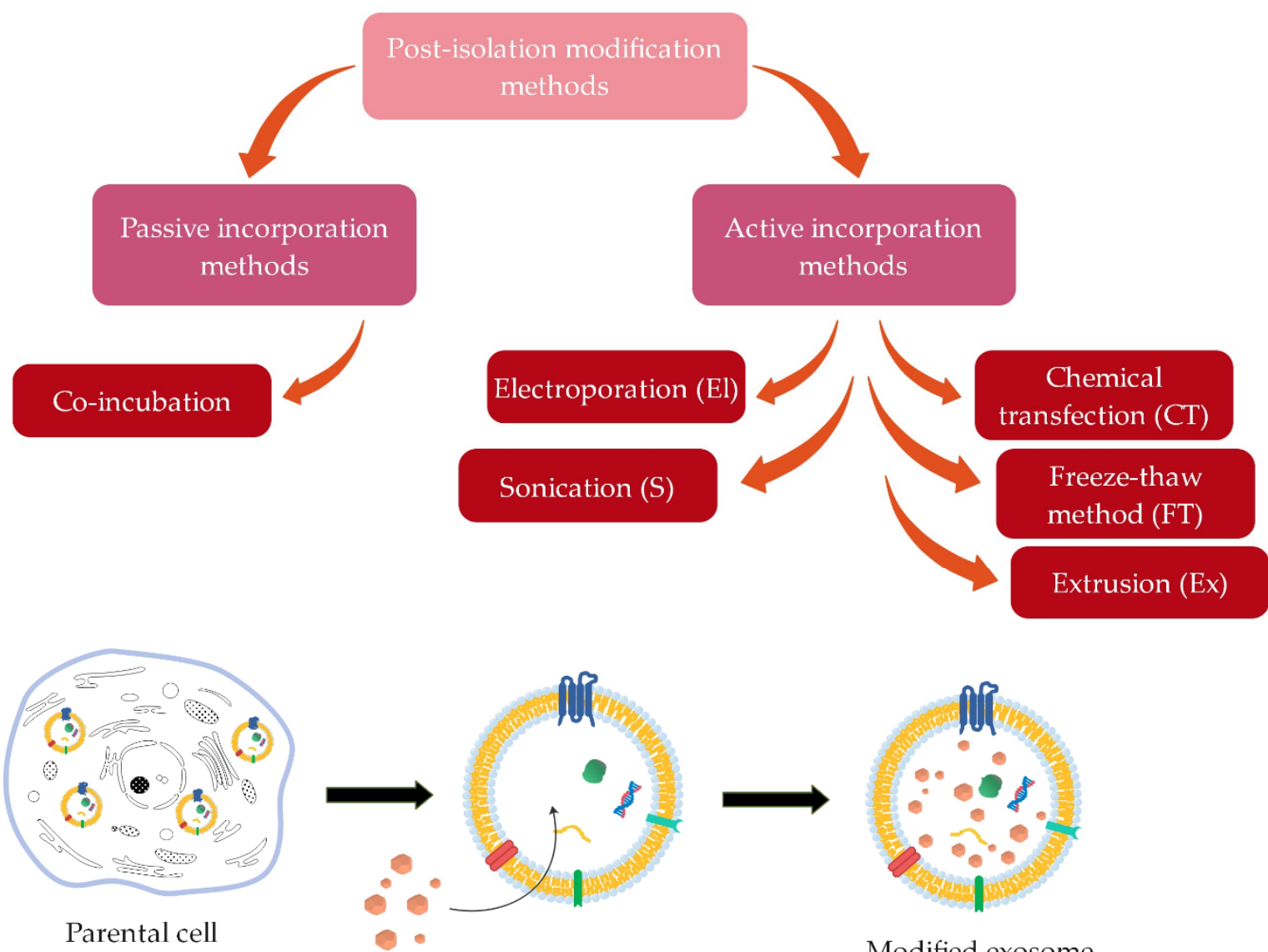

Cargo, e.g., galectin-9 siRNA (El),

Modified exosome gonadotropin (S, FT), lysostaphin and

vancomycin (S), doxorubicin (Ex), siRNA (CT)

Figure 5. Principle of post-isolation exosomes modification methods, where the desired therapeutic agents can be encapsulated in purified exosomes, directly after their isolation from cells, either through passive (co-incubation) or active incorporation methods (summarized from [14-16,79-84]).

\section{Post-Isolation Modification Methods}

Drugs and therapeutic agents can be encapsulated into purified exosomes by postisolation modification methods directly after their isolation from cells, which provides greater efficiency (Figure 5).

This can be achieved through active or passive incorporation $[15,16,85]$. The passive incorporation methods are relatively simple and successful and preserve the morphology 
of exosomes but provide low loading efficiency. They include co-incubation of exosomes and therapeutic agents that can diffuse into the interior of exosomes through the membrane along the concentration gradient $[14,85]$.

On the other hand, active incorporation methods involve different approaches for loading therapeutic agents into exosomes [14]. These methods temporarily disrupt the membrane, allowing the cargo to easily pass into the interior of the exosomes. After the diffusion of the cargo, the membrane integrity of the exosomes is restored [8]. One of the active incorporation methods is electroporation, in which pores are temporarily formed in the phospholipid bilayer of exosomes due to the electric field in a conductive solution, allowing the entry of cargo into exosomes [14,16,86]. Faruqu et al. [79] incorporated fluorescent Atto655-conjugated nonspecific siRNA into exosomes derived from human embryonic kidney cells (HEK-293 cells) by electroporation with 10-20\% efficiency. Zhou et al. [83] also successfully encapsulated galectin-9 siRNA into exosomes derived from bone marrow mesenchymal stem cells (BM-MSCs) with the use of a Gene Pulser $X$ Cell Electroporation System. In the sonication process, the membrane is deformed using ultrasound and a homogenization probe, thus allowing the drug to diffuse into exosomes [14,85]. Human chorionic gonadotropin was efficiently loaded $(40.55 \% \pm 4.21 \%)$ into exosomes isolated from uterine fluid using a sonication process by Hajipour et al. [80]. While Yang et al. [84] achieved $15.52 \% \pm 2.38 \%$ encapsulation efficiency by encapsulating the antibacterial drug lysostaphin into mannosylated exosomes by sonication and $22.15 \% \pm 3.21 \%$ by encapsulating vancomycin. Extrusion is a method in which a mixture of exosomes and cargo is extruded through a membrane with a pore size between 100 and $400 \mathrm{~nm}$ using a lipid extruder. The cargo enters inside the exosomes through a disrupted membrane [16]. Guo et al. [82] encapsulated doxorubicin into exosomes by a magnetic extrusion process. With the ammonium sulfate gradient loading mechanism, they achieved much higher encapsulation efficiency (68\%) than with direct encapsulation $(23 \%)$. In the freeze-thaw method, several cycles of freezing the exosome-cargo mixture at $-80{ }^{\circ} \mathrm{C}$ or in liquid nitrogen and re-thawing to room temperature are repeated to ensure the successful incorporation of drugs $[16,86]$. Hajipour et al. [80] incorporated human chorionic gonadotropin into exosomes from RAW264.7 cells with $14.02 \pm 5.46 \%$ efficiency using the freeze-thaw method. Another method is chemical transfection, in which exosomes and cargo are incubated with the surfactant, causing the formation of pores in the membrane and thus the penetration of drugs. The most frequently used surfactant is saponin, and thus this method is also called saponin-assisted loading [14,78]. Warren et al. [81] established that encapsulation of siRNA into bovine milk-derived exosomes by chemical transfection was significantly more efficient than by electroporation.

\subsubsection{Surface Modifications}

The surface of exosomes is essential for their biodistribution, ability to target specific cells, and therapeutic potential. By modifying the surface the desired characteristics of exosomes can be achieved, thereby improving cell targeting $[14,85,87]$. The exosome's surface can be modified through acting on parental cells that will secrete exosomes or through directly modifying isolated exosomes [16].

\section{Genetic Engineering of Parental Cells}

Modification of the exosome membrane can be obtained through genetic engineering of parental cells [11] (Figure 6). Cells are genetically modified through viral vectors by inserting the coding sequence of the desired ligand. These cells then secrete exosomes with expressed peptides on their surface $[14,16,88]$. 


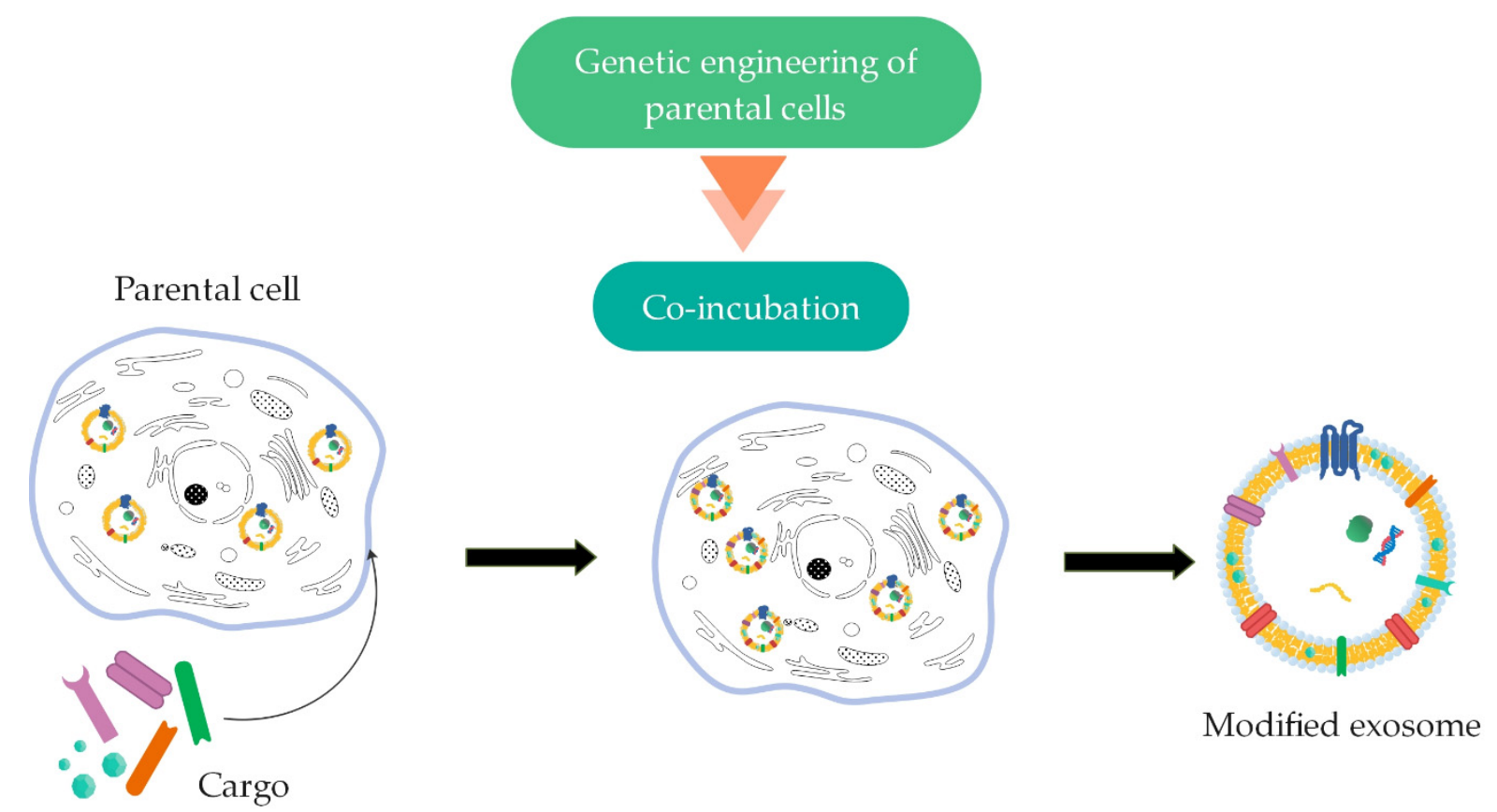

Figure 6. Genetic engineering of parental cells for surface modification of exosomes by the method of co-incubation (summarized from [11,16]).

Direct Modification of Isolated Exosomes

Certain methods have been developed to modify the surface of exosomes after their isolation from cells (Figure 7) in order to achieve a more specific delivery to the target cells [14]. Surface modification of exosomes due to covalent binding can be performed through a crosslinking reaction called click chemistry or azide-alkyne cycloaddition. A reaction between an alkyl and an azide chemical group occurs to form a stable triazole bond [14,16,89]. Using this method, Tian et al. [90] modified the surface of exosomes derived from mesenchymal stem cells (MSCs) with a cyclo(Arg-Gly-Asp-D-Tyr-Lys) peptide [c(RGDyK)] in order to improve targeting abilities. For the same purpose, $\mathrm{Xu}$ et al. [91] fluorescently labeled exosomes from pancreatic cells with a newly developed method based on copper-free click chemistry. However, the surface can also be altered through various non-covalent modification methods. The most commonly used modifications are the receptor-ligand binding method and a multivalent electrostatic approach based on interactions between highly cationic species and negatively charged functional groups on the membrane $[16,89]$.

One of the methods of surface modification is hybridization, wherein exosomes combine with fusogenic liposomes due to the lipid nature of exosomes' membrane. Moreover, due to the exosomes' lipid membrane, hydrophobic components can be incorporated directly onto their surface [85].

\subsection{Synthetic Exosomes}

For the possibility of using modified exosomes for a wide range of therapeutic applications, it is necessary to provide standardized isolation and purification with the appropriate clinical grade of natural exosomes, which is difficult to achieve. Further, suitable modification techniques for incorporation of drugs, genes, and other therapeutic agents, for which not all developed approaches are fully appropriate, also have to be provided. As a result, approaches are being developed to produce completely artificial exosomes using biotechnology that mimic the properties of exosomes. However, there are still not many studies covering the field of synthetic exosomes [20,92]. Two approaches (Figure 8 ) have been developed for synthetic exosome production, cell-based methodology, and lipid membrane bilayer formation methodology. 

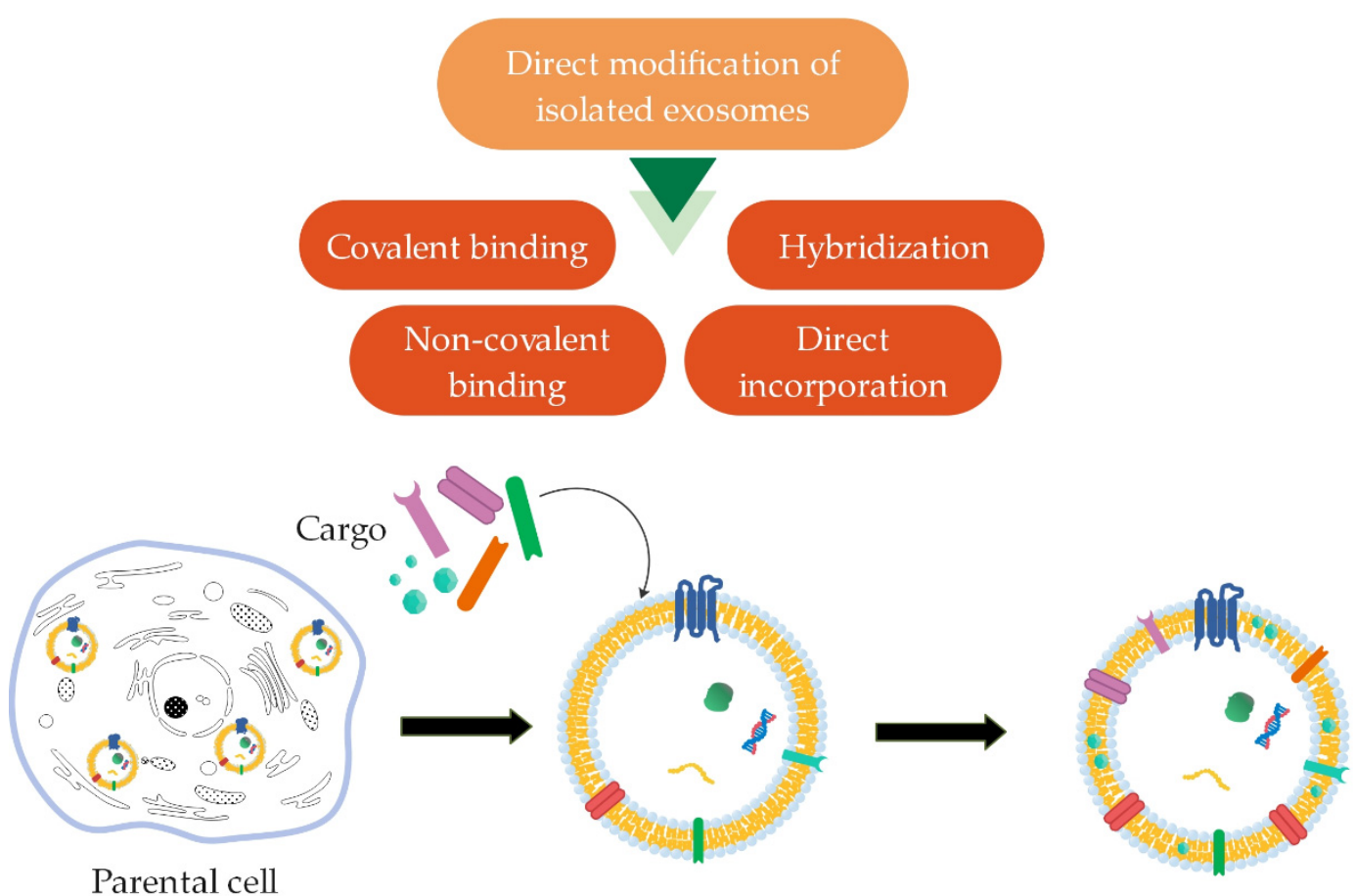

Modified exosome

Figure 7. Direct surface modification of isolated exosomes using different methods (covalent binding, non-covalent binding, hybridization, and direct incorporation; summarized from [16,85]).
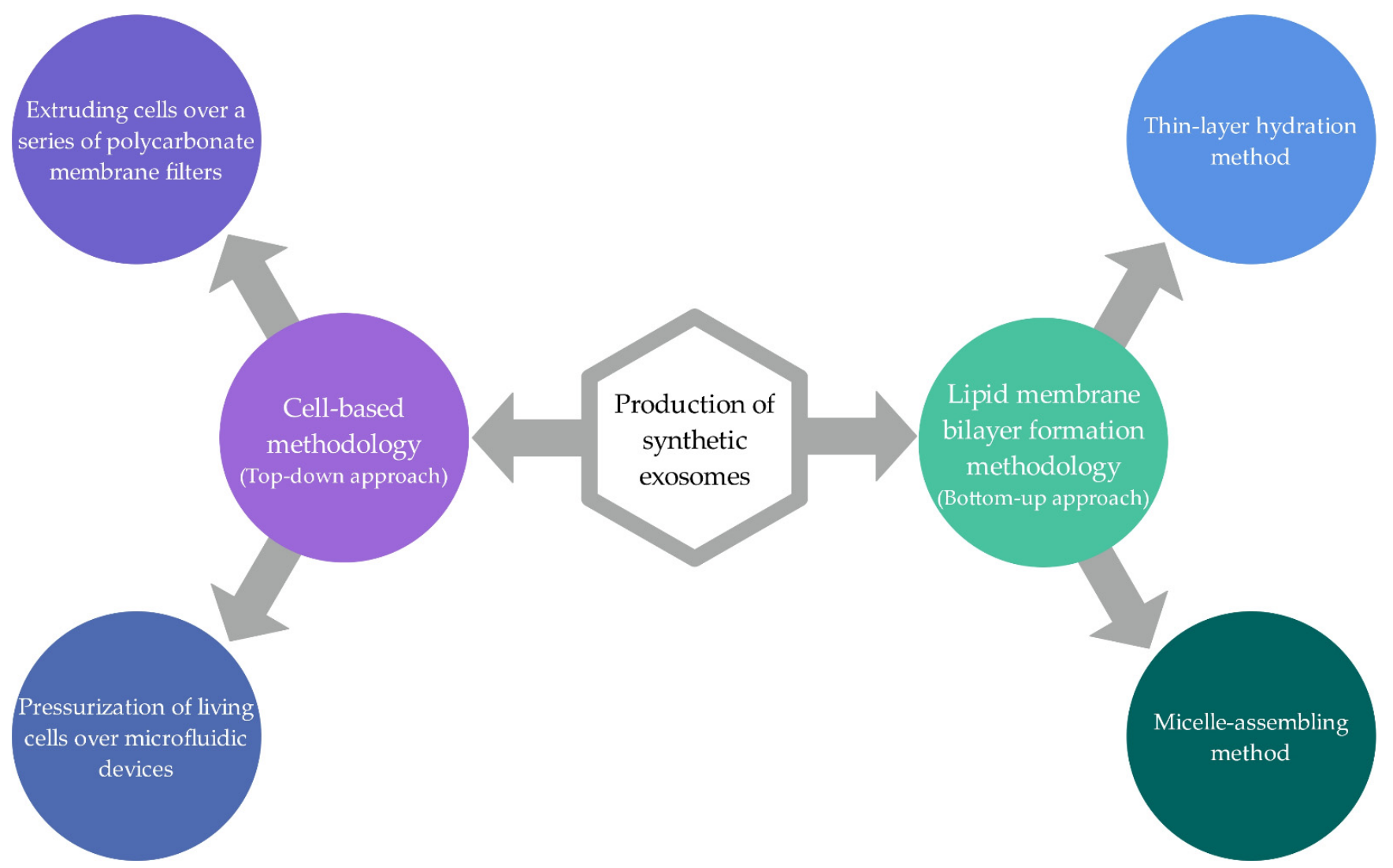

Figure 8. Schematic representation of methodologies for the production of synthetic exosomes—cell-based methodology and lipid membrane bilayer formation methodology (summarized from $[9,20]$ ). 


\subsubsection{Cell-Based Methodology}

The cell-based methodology is based on top-down technology, which is used to fabricate smaller materials from large and complex substrates. In this, cultured cells are used as a basis for the production of synthetic biomaterials, which are broken down into smaller membrane fragments. These fragments assemble themselves into spherical membrane vesicles that carry the same membrane characteristics as the initial cell $[9,14,18,20]$. According to the principle of top-down methodology, exosomes can be produced by different approaches, among which there are two most appropriate and promising methods for producing larger amounts of therapeutic biopolymers similar to naturally isolated exosomes. The first, simpler approach is the process of extruding cells over a series of polycarbonate membrane filters with reduced pore size, producing vesicles of a similar size $[9,14]$. The second approach involves the pressurization of living cells over microfluidic devices, which contain a series of parallel hydrophilic microchannels, whereby the cells are broken down into smaller fragments and then reassembled into vesicles $[9,20]$.

\subsubsection{Lipid Membrane Bilayer Formation Methodology}

In contrast to cell-based methodology, lipid membrane bilayer formation is performed according to the principle of bottom-up methodology, which is based on the production of larger and more complex structures from small components $[14,20]$. For the production of therapeutic biomaterials, special lipids required for the production of the lipid bilayer, specific membrane proteins, and the desired therapeutic components (cargoes) are used as molecular building blocks [18]. Exosomes are structurally and biochemically similar to liposomes, and therefore according to the principle of bottom-up techniques, two main approaches are suitable for the fabrication of exosomes, among various methods for the production of liposomes [14,18]. This is the thin-film hydration method based on the hydration of a dried film and the microemulsion and micelle assembling method [14,20,93]. Some other methods potentially suitable to produce vesicles similar to natural exosomes are reverse-phase evaporation, a method based on ethanol and ether injection, microfluidicbased methods, extrusion methods, and homogenization techniques $[16,18]$. During these production processes, the desired cargo can also be incorporated [9].

Zhang et al. [92] used a combination of bottom-up and top-down approaches in their study to produce artificial chimeric exosomes for anti-phagocytosis and targeted cancer therapy. Exosomes were constructed on the principle of incorporating membrane proteins from different cell types, including red blood cells and MCF-7 cancer cells, into a synthetic phospholipid bilayer. With this approach they were able to closely mimick the morphological and physiological composition of natural exosomes, as well as the anti-tumor therapeutic effect, as shown with a study of mice with subcutaneous injection.

\subsection{Advantages and Disadvantages of the Individual Exosome Preparation Method}

A comparison of the previously mentioned preparation and production methods of modified and synthetic exosomes is presented below based on their advantages and disadvantages.

\subsubsection{Comparison of Modification Methods of Exosome Preparation}

Figure 9 summarizes the advantages (green) and disadvantages (red) of modification methods of exosome preparation. These methods are divided into interior and surface modifications (passive and active incorporation methods).

The simplest method for producing modified exosomes is co-incubation, which can be used as an internal (pre-isolation and post-isolation methods) as well as a surface modification technique. The disadvantage of this method is usually the low efficacy of cargo incorporation. The method of incorporating therapeutic agents into the interior of exosomes directly after their isolation from cells is more successful. Electroporation and extrusion are also simple methods, as are almost all methods of direct modification of isolated exosomes, i.e., covalent binding, non-covalent binding, and direct incorporation. Among the latter, covalent binding is also a rapid and efficient method $[7,11,14,16,85]$. 


\begin{tabular}{|c|c|c|c|}
\hline $\begin{array}{l}\text { Pre-isolation } \\
\text { modification methods }\end{array}$ & & $\begin{array}{l}\text { Post-isolation } \\
\text { dification methods }\end{array}$ & \\
\hline \multirow{4}{*}{\begin{tabular}{|l|}
$\begin{array}{l}\text { Co-incubation } \\
\text { + Relatively simple method } \\
\text { - Impossible to control } \\
\text { incorporation efficacy }\end{array}$ \\
$\begin{array}{l}\text { Gene editing } \\
\text { + Possible incorporation of } \\
\text { RNA and proteins } \\
\text { + Improves loading efficacy } \\
\text { - Time-consuming method }\end{array}$
\end{tabular}} & \multicolumn{2}{|c|}{ Passive incorporation methods } & Active incorporation methods \\
\hline & \multirow{3}{*}{\begin{tabular}{|l|} 
Co-incubation \\
+ Relatively simple \\
and successful \\
+ The morphology of \\
exosomes is preserved \\
- Low efficacy of cargo \\
incorporation
\end{tabular}} & \multirow{2}{*}{$\begin{array}{l}\text { Electroporation } \\
+ \text { A simple and time-saving method } \\
\text { + Enables incorporation of large } \\
\text { molecules (e.g., siRNA and miRNA) } \\
\text { - Possible RNA aggregations } \\
\text { - Possible damage of protein } \\
\text { structure } \\
\text { - Possible membrane damage } \\
\text { - Low efficacy of cargo incorporation }\end{array}$} & $\begin{array}{l}\text { Sonication } \\
+ \text { High efficacy of cargo incorporation } \\
\text { - Possible aggregations of exosomes } \\
\text { - Possible membrane damage } \\
\text { - Only efficient for hydrophilic drugs }\end{array}$ \\
\hline & & & $\begin{array}{l}\text { Chemical transfection } \\
\text { + High efficacy of cargo incorporation } \\
\text { - Possible membrane damage } \\
\text { - Possible toxicity }\end{array}$ \\
\hline & & $\begin{array}{l}\text { Extrusion } \\
\text { + Simple method } \\
\text { + High efficacy of cargo incorporation } \\
\text { + Uniform size of produced exosomes } \\
\text { - Possible membrane damage }\end{array}$ & $\begin{array}{l}\text { Freeze-thaw method } \\
+ \text { Medium efficacy of cargo } \\
\text { incorporation } \\
\text { - Aggregation of exosomes } \\
\text { - Modification of membrane properties }\end{array}$ \\
\hline
\end{tabular}

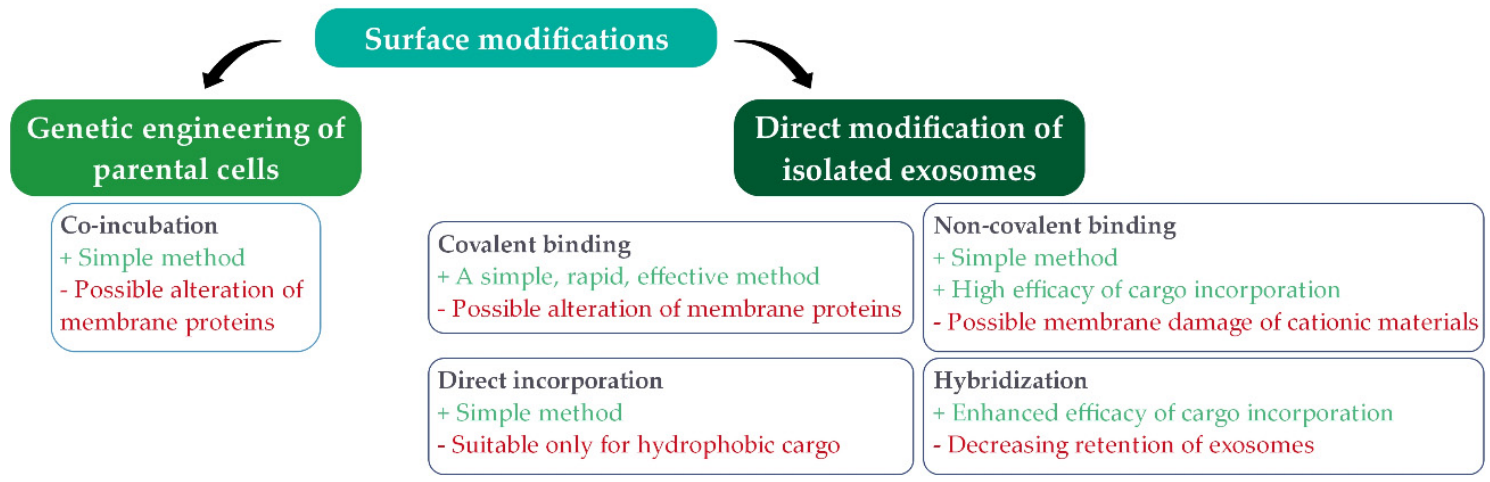

Figure 9. The main advantages (green) and disadvantages (red) of exosome preparation methods for interior (pre-isolation and post-isolation modification methods) and surface modifications (genetic engineering of parental cells and direct modification of isolated exosomes; summarized from $[7,11,14,16,78,85,89,90,94-96])$.

The efficiency of cargo incorporation into the interior of exosomes is extremely high in the case of sonication, chemical transfection, and extrusion. However, the mentioned methods also have some disadvantages that play a crucial role in choosing a method for cargo loading inside exosomes. In particular, they can cause deformation of the membrane of exosomes, while chemical transfection also has possible toxicity to living cells. In contrast, the incorporation in the freeze-thaw method is only moderately effective and low in the co-incubation method. Although electroporation does not have a high efficiency of cargo incorporation, it is suitable for the incorporation of large components into exosomes, such as siRNA and miRNA, but RNA aggregation is possible. In the case of surface modifications, non-covalent binding and hybridization are methods with high efficiency of incorporating cargo onto the exosomes' surface. Most of the preparation methods of modified exosomes can lead to membrane damage or alteration of surface proteins. The only exception is co-incubation in internal modifications as well as hybridization and direct incorporation in surface modifications $[14,16,85,89,94-96]$.

Some methods are only suitable for loading hydrophilic cargo, such as sonication (incorporation of cargo into the hydrophilic interior of exosomes), while others are only suitable for loading hydrophobic cargo, such as direct incorporation (incorporation of cargo onto exosomes hydrophobic surface) $[85,95]$.

Due to the possible incorporation of RNA and proteins without destroying the structure of RNA, gene editing is a highly suitable method for biomedical applications, especially for gene delivery. However, it is a time-consuming method [11,95]. 
As presented above, there is no most ideal method of exosome preparation. Each method has certain advantages or disadvantages. Therefore, the choice of the exosome production method itself depends on various requirements, such as the type and size of molecules for incorporation, simplicity of the method, available equipment, loading efficiency, etc.

\subsubsection{Comparison of Methodologies for Synthetic Exosome Production}

Table 1 presents the advantages and disadvantages of methodologies for synthetic exosome production, with both cell-based and lipid membrane bilayer formation methods.

Table 1. The main advantages and disadvantages of the various methods for synthetic exosome production $[9,14,16,18,20,85,92,97,98]$.

\begin{tabular}{ccc}
\hline Methodology & Cell-Based Methodologies & Lipid Membrane Bilayer Formation Methodologies \\
\hline Advantages & $\begin{array}{c}\text { Suitable for mass production } \\
\text { Production of exosomes similar to } \\
\text { natural exosomes } \\
\text { Immunotolerant, due to their origin from cells }\end{array}$ & $\begin{array}{c}\text { Production of extremely pure nanoparticles with the } \\
\text { desired composition (high pharmaceutical } \\
\text { grade products) }\end{array}$ \\
Disadvantages & $\begin{array}{c}\text { Time-consuming } \\
\text { Sultable for the study of the individual elements }\end{array}$ \\
\hline Hard to control the production process & $\begin{array}{c}\text { Use of extremely expensive lipids with high purity } \\
\text { Risk of losing protein functions during production } \\
\text { The need for deep knowledge of the composition } \\
\text { of exosomes }\end{array}$ \\
\hline
\end{tabular}

Compared with the preparation of modified exosomes, synthetic exosome production has some advantages. Extremely large amounts of exosomes can be obtained with cellbased methods, while extremely pure products with a known composition can be produced using the lipidmembrane bilayer formation methods $[9,14,20,85]$.

Given the different advantages and disadvantages of both approaches for synthetic exosome production, it cannot be confirmed which method is optimal. The production approach depends on how pure a product or how much of a product one wants to obtain, what specifications are required, and the primary purpose of their use. Nevertheless, they also have key disadvantages as they are more expensive or time-consuming methods, and there is a great need for deep knowledge of the composition of exosomes.

\subsection{Incorporation of Cargo into Therapeutic Biomaterials}

Exosomes consist of a hydrophobic lipid membrane bilayer and a hydrophilic core (Figure 10). Due to surface modification in order to improve exosome imaging and cell targeting, various hydrophobic therapeutic components (e.g., paclitaxel and curcumin) can be incorporated into the lipid membrane bilayer. This can improve the stability and efficacy of the incorporated drugs. In contrast, numerous hydrophilic therapeutic cargoes, including hydrophilic drugs and macromolecules, such as RNA, DNA, and proteins, can be incorporated into the core of exosomes and thereby improve cell delivery [96,99-101].

Hydrophilic compounds are not able to pass naturally through the lipid bilayer; therefore, different methods have been developed to incorporate various compounds into exosomes. These methods create pores through which hydrophilic compounds can enter into exosomes [102], and are briefly described in Section 2.2.1. For the incorporation of hydrophobic compounds, the method of co-incubation of exosomes with hydrophobic therapeutic agents alone is sufficient, as they can easily pass into the membrane [102] However, this method is only recommended for smaller hydrophobic molecules, and therefore other modification methods are also used for the incorporation of lipophilic molecules [103]. 


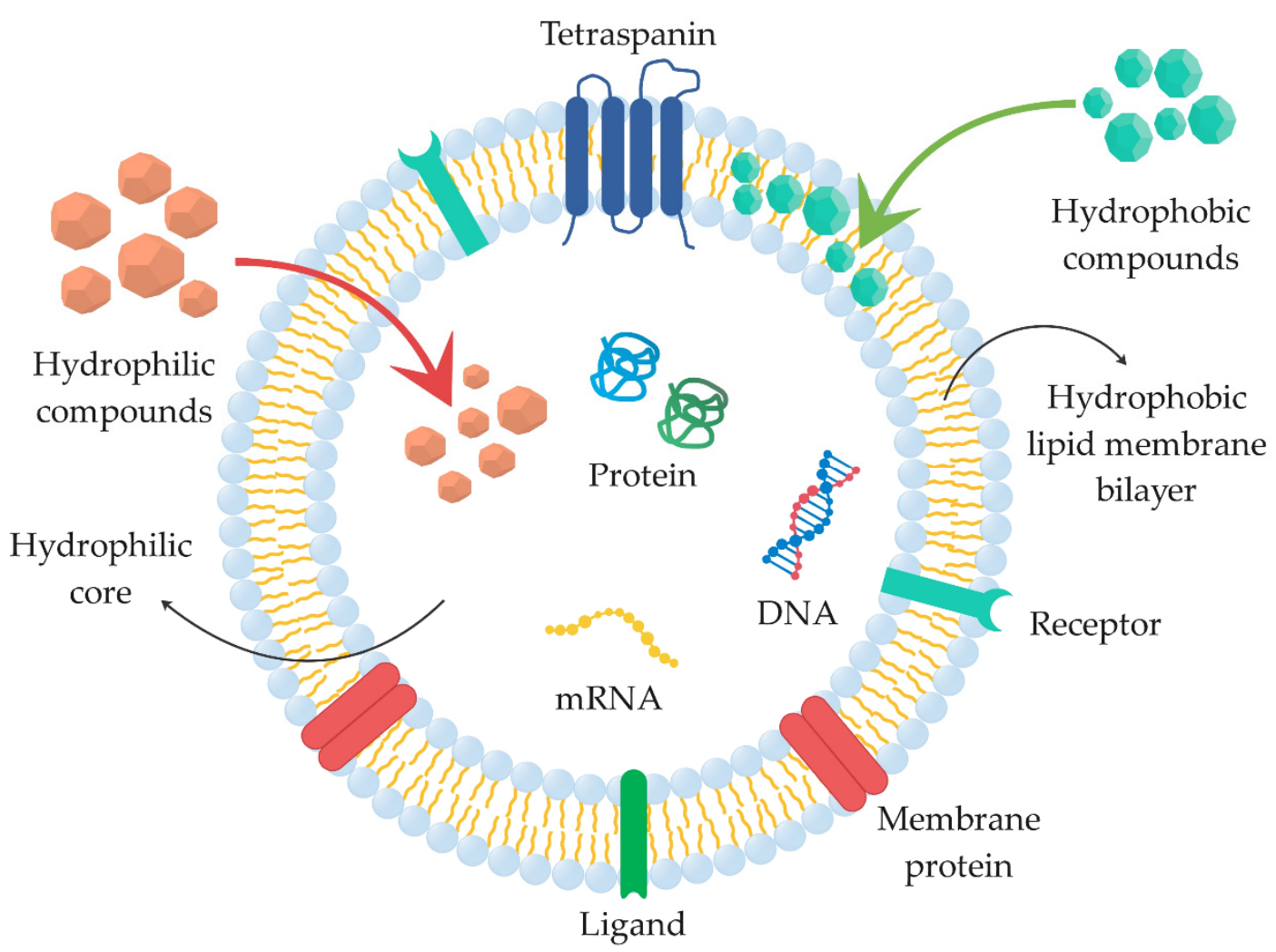

Figure 10. Incorporation of hydrophilic (e.g., melatonin, gemcitabine, linezolid, vancomycin, and lysostaphin) and hydrophobic (e.g., curcumin, paclitaxel, doxorubicin, and aspirin) cargo into hydrophilic core and hydrophobic lipid membrane bilayer of exosomes (summarized from [7,76,84,85,100,102,104-110]).

Various methods such as co-incubation, saponin-assisted loading, the freeze-thaw method, sonication, and extrusion can effectively incorporate proteins, especially the enzyme catalase, without altering the structure of the exosomes significantly. In addition, due to the preserved enzymatic activity of catalase, such modified exosomes effectively reduce oxidative stress and produce a strong neuroprotective effect, representing potential use in the treatment of inflammation, stroke, and neurodegenerative diseases, particularly Parkinson's disease and Alzheimer's disease, and infectious diseases, such as meningitis, encephalitis, and neurocognitive disorders in HIV-infected individuals [111]. Exosomes modified with therapeutic peptides and hydrophobic components such as curcumin can successfully reduce inflammation in the lungs. Therefore, such modified exosomes could be useful in the treatment of fatal respiratory diseases, including acute lung injury [112]. Lipophilic and water-insoluble components are more difficult to deliver to the target site and thus ensure adequate therapeutic efficacy. Exosomes have become potential carriers of these components due to their lipid bilayer membrane, into which hydrophobic therapeutics can be incorporated, thereby their importance for biomedical applications has increased. In addition, exosomes with the incorporated hydrophobic anticancer drug may increase the cytotoxicity of the drug, which may lead to the development of safe and improved cancer therapy [113]. Table 2 presents some examples of incorporated hydrophobic and hydrophilic components into exosomes by different methods from recent studies from the last three years. 
Table 2. Examples of different types of cargo incorporated into naturally derived exosomes through modification methods.

\begin{tabular}{|c|c|c|c|c|}
\hline Incorporated Cargo & Exosome Source & Modification Method & Results & Ref. \\
\hline \multicolumn{5}{|c|}{ Hydrophobic Cargo (Incorporated Into Membrane) } \\
\hline Curcumin & $\begin{array}{l}\text { Murine macrophage } \\
\text { RAW264.7 cells }\end{array}$ & Co-incubation & $\begin{array}{l}\text { Good stability, inflammation-specific } \\
\text { targeting ability, antioxidant features }\end{array}$ & [104] \\
\hline \multirow{3}{*}{ Paclitaxel } & \multirow{2}{*}{ U-87 cell } & Co-incubation & \multirow{2}{*}{$\begin{array}{l}\text { Toxicity effect against glioblastoma } \\
\text { multiforme cells }\end{array}$} & \multirow{2}{*}{ [105] } \\
\hline & & Sonication & & \\
\hline & M1-macrophages & Sonication & Enhanced antitumor effects & [106] \\
\hline Doxorubicin & HEK293 cell line & Electroporation & $\begin{array}{l}\text { Rapid uptake into recipient cells, } \\
\text { increased potency }\end{array}$ & [107] \\
\hline Aspirin & $\begin{array}{l}\text { Breast and colorectal } \\
\text { cancer cells }\end{array}$ & $\begin{array}{c}\text { Modified } \\
\text { freeze-thawing process }\end{array}$ & $\begin{array}{l}\text { Enhanced cellular uptake, improved } \\
\text { cytotoxicity, anti-tumor effects }\end{array}$ & [108] \\
\hline \multicolumn{5}{|c|}{ Hydrophilic Cargo (Incorporated Into Core) } \\
\hline Melatonin & MSCs & $\begin{array}{c}\text { Co-incubation } \\
\text { (pre-isolation method) }\end{array}$ & $\begin{array}{l}\text { Improved kidney recovery } \\
\text { and function }\end{array}$ & [76] \\
\hline $\begin{array}{l}\text { Doxorubicin } \\
\text { hydrochloride }\end{array}$ & BM-MSCs & Co-incubation & Cytotoxicity in osteosarcoma cells & [114] \\
\hline Gemcitabine & $\begin{array}{l}\text { Pancreatic cancer cells } \\
\text { (Panc-1) }\end{array}$ & $\begin{array}{l}\text { Co-incubation } \\
\text { Sonication }\end{array}$ & $\begin{array}{l}\text { Improved cellular uptake, therapeutic } \\
\text { efficacy against pancreatic cancer, } \\
\text { minimal damage to normal tissues }\end{array}$ & [109] \\
\hline Linezolid & Mouse RAW 264.7 cells & Co-incubation & $\begin{array}{l}\text { Efficacious intracellular } \\
\text { antibiotic delivery }\end{array}$ & [110] \\
\hline $\begin{array}{l}\text { Vancomycin and } \\
\text { lysostaphin }\end{array}$ & RAW264.7 cells & Sonication & Antimicrobial efficiency & [84] \\
\hline \multicolumn{5}{|c|}{ Other Cargo } \\
\hline Imperialine & Human plasma & $\begin{array}{l}\text { Micelle-aided loading } \\
\text { method }\end{array}$ & Increased antitumor effects & [115] \\
\hline \multirow{3}{*}{ siRNA } & Bovine milk & $\begin{array}{c}\text { Electroporation } \\
\text { Chemical transfection }\end{array}$ & Anti-tumor efficacy & [116] \\
\hline & Breast cancer cell & Co-incubation & $\begin{array}{l}\text { Suppression of postoperative } \\
\text { metastasis (in triple negative } \\
\text { breast cancer) }\end{array}$ & [117] \\
\hline & $\begin{array}{l}\text { Human normal MRC-5 } \\
\text { fibroblasts cells } \\
\text { Monkey normal Vero } \\
\text { epithelial cells }\end{array}$ & Co-incubation & Increased cellular uptake efficiency & [118] \\
\hline $\begin{array}{l}\text { Hollow gold } \\
\text { nanoparticles }\end{array}$ & Murine melanoma cells & $\begin{array}{l}\text { Electroporation } \\
\text { Diffusion } \\
\text { Thermal shock } \\
\text { Sonication } \\
\text { Saponin-assisted } \\
\text { loading }\end{array}$ & High encapsulation yield & [119] \\
\hline $\begin{array}{l}\mathrm{c}(\mathrm{RGDyK}) \text { peptide } \\
\text { and curcumin }\end{array}$ & BM-MSCs from mice & Click chemistry & $\begin{array}{l}\text { Suppression of the inflammatory } \\
\text { response and cellular apoptosis in the } \\
\text { lesion region }\end{array}$ & [90] \\
\hline
\end{tabular}

Nanovesicles produced from a variety of plant sources have similar properties to mammalian exosomes. Therefore, just as various therapeutic agents can be incorporated into mammalian exosomes, different therapeutic cargo, such as small molecular drugs, siRNAs, DNA expression vectors, and proteins [70], can also be incorporated into plant exosomes, as shown in Table 3, which includes some examples from studies from the last 
six years. Moreover, edible plant exosomes are non-toxic and can be produced on a large scale [120].

Table 3. Plant-based exosomes and their potential use as drug delivery vehicles.

\begin{tabular}{|c|c|c|c|}
\hline Exosome Source & Incorporated Cargo & Results & Ref. \\
\hline Strawberry & - & $\begin{array}{l}\text { Strawberry-derived exosomes have been taken up by } \\
\text { human MSCs. There was no trace of cytotoxicity, they } \\
\text { even prevented oxidative stress in the human cells }\end{array}$ & [74] \\
\hline \multirow{3}{*}{ Ginger } & Doxorubicin & $\begin{array}{c}\text { Effective inhibition of tumor growth in the Colon-26 } \\
\text { xenograph tumor model }\end{array}$ & [120] \\
\hline & $\begin{array}{l}\text { Naturally occurring components: } \\
\text { lipids, proteins, mRNA, } \\
\text { 6-gingerol and 6-shogaol }\end{array}$ & $\begin{array}{l}\text { Reduction in acute colitis, enhanced intestinal repair, and } \\
\text { prevented chronic colitis and colitis-associated cancer. } \\
\text { Potential for preventing inflammatory bowel disease }\end{array}$ & [121] \\
\hline & - & $\begin{array}{c}\text { Inhibition of NLRP3 inflammasome assembly } \\
\text { and activation }\end{array}$ & [122] \\
\hline Grapefruit & $\begin{array}{l}\text { Inflammatory chemokine receptor, } \\
\text { doxorubicin, or curcumin }\end{array}$ & $\begin{array}{l}\text { Inhibition of tumor growth, inhibition of inflammatory } \\
\text { effects of dextran sulfate sodium-induced mouse colitis }\end{array}$ & [123] \\
\hline Broccoli & Sulforaphane & Prevention of DSS-induced colitis in B6 mice & [124] \\
\hline Turnip & \multirow[t]{2}{*}{ - } & \multirow{2}{*}{ Inhibition of MCF-7 cells proliferation } & \multirow{2}{*}[125]{} \\
\hline Lemon & & & \\
\hline Apple & Naturally occurring microRNA & $\begin{array}{l}\text { Decreased OATP2B1 expression in human epithelial } \\
\text { colorectal adenocarcinoma (Caco-2) cells at the } 4 \text { levels of } \\
\text { mRNA, protein content, and transport activity }\end{array}$ & [126] \\
\hline
\end{tabular}

In the next section, various promising applications of therapeutic exosomes are presented, with an emphasis on the delivery of drugs and other therapeutic agents.

\section{Therapeutic Applications of Exosomes}

Due to the aforementioned properties, exosomes obtained from various sources and modified by different processes or synthetically produced can be used for a variety of biomedical applications (Figure 11) [15]. They can be used in drug delivery, gene therapy, vaccine development, tissue regeneration, and as biomarkers in the diagnosis and therapy of various diseases, such as cardiovascular diseases, cancer, neurodegenerative diseases, skin regeneration, arthritis, diabetes, and for immunological purposes [15,21,127-129].

Exosomes are stable therapeutic biomaterials, even in digestive and other biological fluids, and are therefore highly effective for long-distance intracellular communication. They also possess a natural targeting ability due to their unique surface composition. However, their targeting ability to recipient cells varies according to their origin. In order to make exosomes easier for the receiving cells to recognize, certain molecules can be incorporated into them. Exosomes can offload their cargo into target cells through membrane fusion or phagocytosis [8].

\subsection{Biomarkers}

Biomarkers are important for the early detection of disease and effective therapy. They must be specific, noninvasive, and have high stability. As there is currently a lack of such biomarkers, more attention is being paid to exosomes and their content as promising biomarkers [130-133]. Exosomes can be isolated from various body fluids and contain components of the cell from which they are secreted, and therefore are easily accessible for diagnosis and studying complex diseases, as they act as a fingerprint of parental cells [134] and reflect their pathological status [135]. Exosomes are already being used as biomarkers, most commonly for the diagnosis of cancer, as well as for cardiovascular 
diseases, central nervous system disorders, and infectious diseases $[11,127,136]$, and are sensitive and reliable [137].

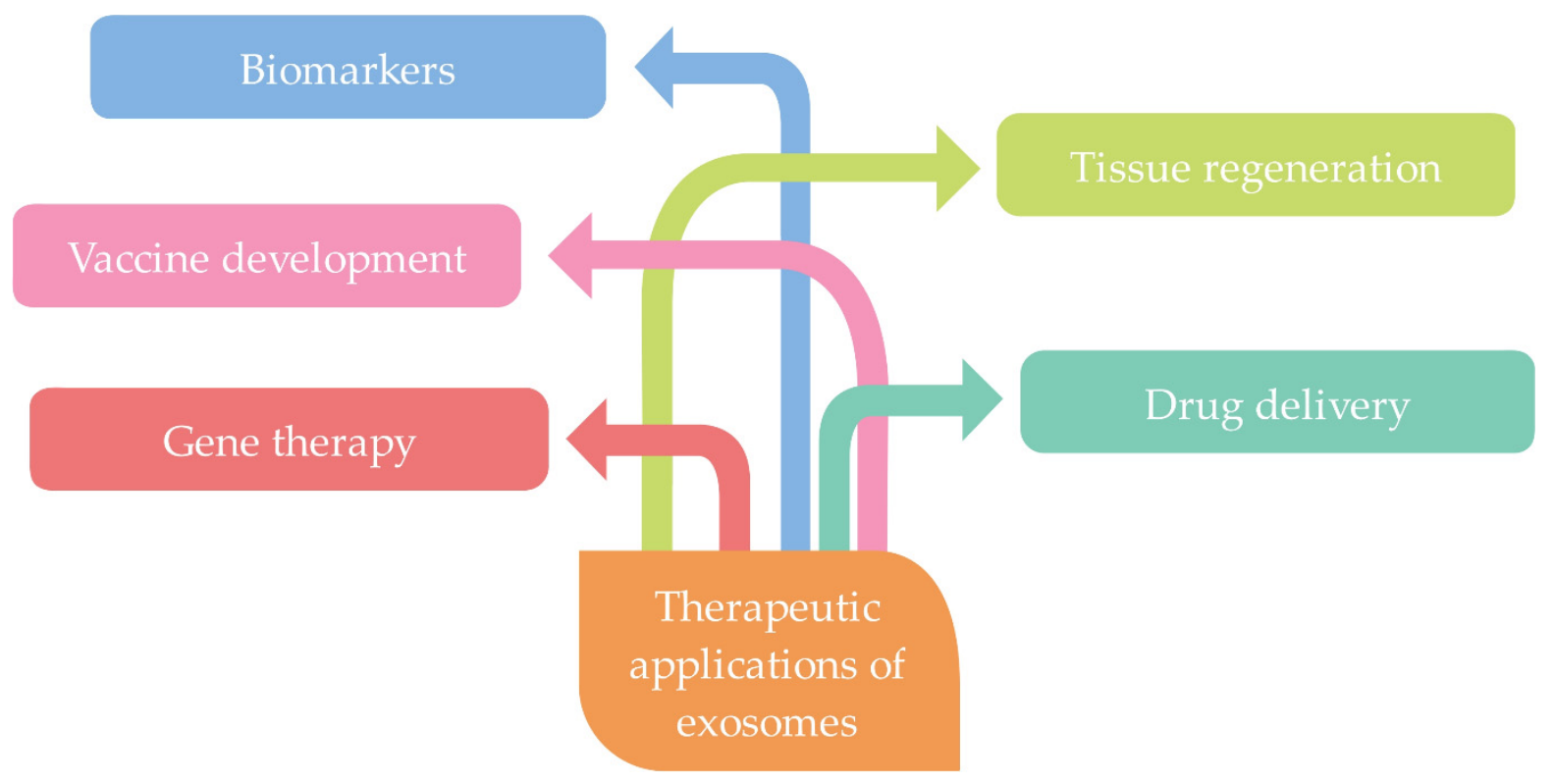

Figure 11. Schematic representation of various therapeutic applications (e.g., gene therapy, vaccine development, tissue regeneration, drug delivery, and as biomarkers in the diagnosis and therapy) of exosomes (summarized from [15,21]).

Jia et al. [138] determined in their study that exosome proteins derived from neurons (GAP43, neurogranin, SNAP25, and synaptotagmin 1) have diagnostic potential for Alzheimer's disease and amnestic mild cognitive impairment. In addition, a combination of exosomal synaptic proteins can predict Alzheimer's disease approximately 5-7 years before cognitive impairment. Among others, exosomes play a significant role in the regulation of skin homeostasis, as well as in skin regeneration and as therapeutics and biomarkers in various dermatological diseases, including melanoma, Merkel cell carcinoma, cutaneous pigmentation, and psoriasis [29].

\subsection{Vaccine Development}

Exosomes have many potential applications for biomedical purposes and, among others, can also be used as vaccination vectors. Recently, much attention has been paid to the possibility of their use as cell-free vaccines against cancer and in immune therapy [139-143]. On the other hand, exosomes also play an important role in the design of vaccines against various infectious diseases, as they can modulate immune responses. They could especially be used in combatting bacterial infections, as they could potentially identify and kill pathogens [144]. They also have the potential to provide an effective approach for the development of virus-free vaccines due to their ability to deliver antigens to target cells. Based on this and on various properties such as anti-inflammatory, proangiogenic, and immunomodulatory activity of exosomes, much attention is currently being paid to exploring the potential for immunomodulatory treatment in patients infected with SARS-CoV-2, especially exosomes derived from MSCs $[145,146]$.

\subsection{Gene Therapy}

Gene therapy does not use a therapeutic approach to alleviate symptoms as in conventional treatment therapy, but this therapy is aimed at the complete cure or elimination of the disease. It is especially important in individuals with congenital genetic disorders. Because bio-vectors currently used in gene therapy can have several adverse side effects in individuals, and because they must be non-toxic while providing a high level of efficiency, exosomes as bio-vectors have become increasingly important in this field as well $[147,148]$. 
Stem cell exosomes have many advantages over other vectors in gene therapy in the treatment of cardiovascular diseases. The most important advantage is that their membrane can effectively protect the cargo (RNA/gene) from digestion during delivery, and that target cells can take them up quickly and efficiently. Therefore, exosomes can be highly efficient carriers in gene delivery [149]. Li et al. [150] demonstrated that exosomes are adequate vectors in the treatment of familial hypercholesterolemia, which may lead to atherosclerosis and cardiovascular diseases. The incorporated mRNA in exosomes was stable and successfully translated into functional proteins in target cells, resulting in reduced lipid deposition in the liver and reduced serum LDL-cholesterol levels. Vakhsiteh et al. [151] used XMIRXpress-34a lentivectors to genetically modify dental pulp MSCs (DPSCs) with tumor suppressor miR-34a, from which exosomes with incorporated miR-34a were then isolated, which showed anticancer effects on breast cancer cells in vitro.

\subsection{Tissue Regeneration}

It has been shown that various complications can occur in traditional tissue engineering, and the efficiency of regeneration itself can be relatively low. Therefore, due to their good characteristics, minimal side effects, and potentially good efficacy, exosomes have also begun to be used in this field [152-154].

In tissue engineering, MSCs are primarily used to fabricate and induce the complete replacement of damaged functional tissues or organs. Various studies have shown that exosomes secreted from MSCs are important in the regeneration of bones, muscles, blood vessels and nerves, cartilage, dentin, as well as in oral and craniofacial regeneration. By modifying exosomes, nanoparticles with adequate characteristics for successful tissue regeneration can be created [155]. Li et al. [156] constructed a cell-free tissue-engineered system by combining exosomes derived from adipose-derived stem cells (hASCs) with poly(lactic-co-glycolic acid) scaffolds with a polydopamine coating (PLGA/pDA). These scaffolds have successfully accelerated bone regeneration in critical-sized calvarial bone defects in mice.

\subsection{Delivery of Drugs and Therapeutic Agents}

Due to their specific characteristics, exosomes could be efficiently used as vehicles for the delivery of drugs and other therapeutic agents, particularly exosomes secreted from MSCs and tumor cells, due to their therapeutic potential, and from immune cells, from which exosomes can be economically obtained on a large scale [9,157]. Many studies have already confirmed the use of exosomes as potentially effective nanocarriers for drugs and therapeutic agents [66,127,158-160].

Exosomes with encapsulated curcumin have been shown to increase the solubility, stability, and bioavailability of curcumin, as compared with free curcumin, as well as increased drug penetration through the blood-brain barrier, which is difficult to achieve with conventional drugs. In addition, curcumin-encapsulated exosomes have great potential in the treatment of Alzheimer's disease, as a study on mice showed improved cognitive functions [161]. Similarly, exosomes incorporated with chemotherapeutic agent Paclitaxel show greater cytotoxicity to glioblastoma multiforme cells than Paclitaxel alone [105]. Exosomes isolated from MSCs with incorporated melatonin compared with exosomes without incorporated melatonin showed better therapeutic and protective properties in renal damage caused by renal ischemia-reperfusion injury [76].

These therapeutic nanocarriers are promising in the treatment of breast cancer as they improve the effectiveness of therapeutic agents [162,163]. They are being developed as important drug suppliers, primarily for the treatment of chemotherapy-resistant patients [164]. Macrophage-derived exosomes can carry miRNA, thereby regulating resistance to chemotherapy. Li et al. [165] achieved highly effective targeted chemotherapy of triple-negative breast cancer using macrophage-derived exosomes with incorporated poly(lactic-co-glycolic acid) (PLGA) nanoparticles loaded with doxorubicin and with an additional modified surface with a peptide for improved tumor targeting efficiency. This 
also enhanced the cellular uptake and antitumoral efficacy of the loaded drug, as well as increased growth inhibition and cell death of tumor cells. Exosomes with an encapsulated adequate antibiotic or other therapeutic agent may help treat intracellular infections caused by pathogenic microorganisms, as they represent a safe, successful, and cost-effective method. Yang et al. [110] formulated nanovesicles to overcome methicillin-resistant Staphylococcus aureus (MRSA)-induced infection. The synthetic antibiotic linezolid was incorporated into exosomes produced from mouse RAW264.7 macrophages. The use of exosomes with incorporated linezolid has been shown to be a more effective therapeutic method in the treatment of MRSA infections, both in vivo and in vitro, in comparison with the administration of free linezolid. It was also determined that the prepared therapeutic biomaterials did not cause cytotoxicity in macrophages.

Exosomes with or without modification are particularly ideal in the delivery of drugs and other therapeutic agents, which can be introduced into the body through different administration routes.

Figure 12 shows the pathway of the production of exosomes for use as drug carriers.

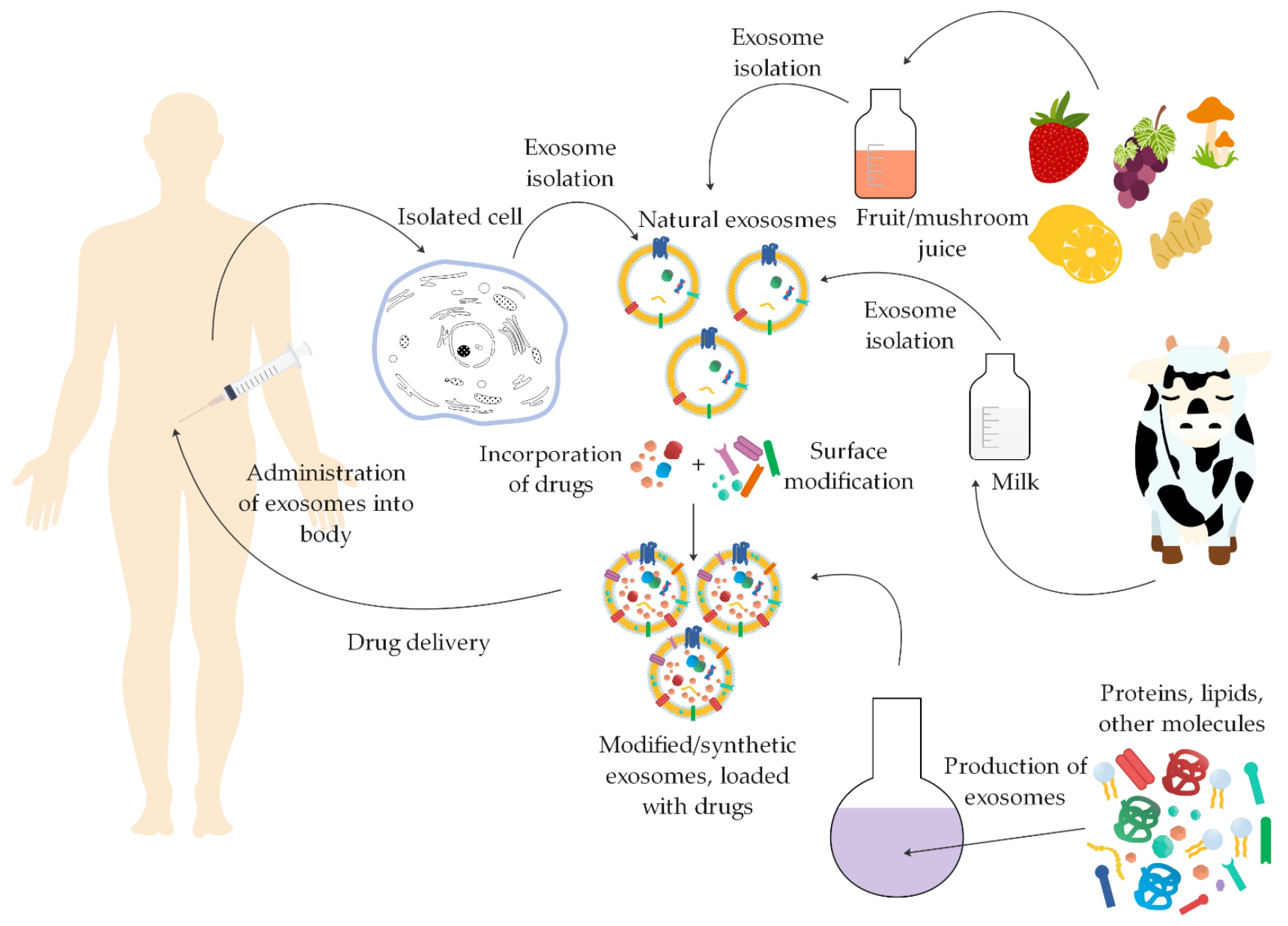

Figure 12. The pathway of production (synthetic or modified) or isolation (natural) of exosomes for use as drug delivery vehicles through various routes of administration into the body (summarized from $[14,16,18,20,74,75,85,122,125]$ ).

\section{Drug Delivery of Therapeutic Biomaterials through Different Administration Routes}

Compared with the conventional administration of drugs in free form, drug delivery via nanocarriers is becoming an increasingly important system as it improves treatment efficacy. The use of conventional therapies can also damage healthy cells [166].

For successful drug delivery, drug delivery vehicles must meet certain criteria. It is necessary that an adequate amount of the drug can be incorporated into drug carriers and 
at the same time ensure the specific delivery of drugs and appropriate therapeutic effect. They must be non-toxic or with extremely low toxicity and biocompatible with the response of the immune system to prevent their degradation before they reach their targets. Many exosomes have these characteristics. In addition, they are small, have extremely low toxicity, and can cause a low rate of long-term accumulation in organs and tissues $[66,127,167]$. They can also cross various biological fluids and pass through plasma membranes, thus delivering therapeutic compounds into the cytoplasm of target cells [147]. Therefore, exosomes have high potential as delivery vehicles of therapeutic agents, particularly because they can also cross the blood-brain barrier [168,169]. Compared with other drug carriers, due to the abovementioned properties, they have a greater potential to be used for biomedical purposes, especially in the treatment of more difficult to treat diseases, including cancer, neurodegenerative diseases, and cardiovascular diseases [139]. One of the advantages is also that exosomes can be utilized for the development of cell-free therapeutics that are safer than cell therapy $[170,171]$. For effective delivery of therapeutic agents, they need to be successfully incorporated into exosomes [172].

Drug delivery through therapeutic biomaterials, such as exosomes, is generally considered as a safe method. However, after dosing, immune responses are possible to occur since exosomes produced from human cells are mainly used, and this can lead to immunogenicity and toxicity, as well as increased clearance of exosomes from the body. On the other hand, exosomes are still safer compared with other synthetic drug nanocarriers. However, the choice of cells used to isolate the desired exosomes is highly important. [102].

The route of drug administration into the body and dosage are also significant in drug delivery. There are various routes of administration of therapeutic biomaterials, such as intravenous injection, subcutaneous injection, intraperitoneal injection, intratumoral injection, intranasal administration, oral administration, and intradermal administration. The route of administration of therapeutic biomaterials affects their distribution in tissues. Among all the mentioned routes, the intravenous route of therapeutics administration is the most commonly used and researched $[2,11,102,147,173]$. A brief description of the abovementioned administration routes of therapeutic biomaterials into the body through drug delivery (Figure 13), based on various studies performed in animal models, is presented below.

\subsection{Drug Delivery through Intravenous Injection}

Intravenous injection, administration of drugs into the vein, is the most common route of administration, although it can lead to the accumulation of exosomes in the liver, spleen, and lung, and they can also be cleared from the circulation extremely quickly [173].

Qu et al. [174] determined that exosomes produced from mouse blood reticulocytes and loaded with dopamine have better therapeutic abilities in the treatment of Parkinson's disease than compared with free dopamine. Dopamine-incorporated exosomes showed the ability to cross the blood-brain barrier, as well as lower systemic toxicity when administrated intravenously to mice. Intravenous or subcutaneous injection of exosomes from human adipose MSCs into mice resulted in improvement in atopic dermatitis [175].

\subsection{Drug Delivery through Oral Administration}

Therapeutic biomaterials do not accumulate in the liver to the same extent as compared with intravenous injection with oral administration. In addition, exosomes remain stable throughout the gastrointestinal tract due to their specific characteristics [176]. Exosomes derived from bovine milk and with incorporated Paclitaxel showed remarkable inhibitory properties on tumor growth in a mouse study compared with the same dose of Paclitaxel administrated intraperitoneally. In addition, they showed significantly lower systemic and immunogenic toxicity compared with intravenous injection $[177,178]$. 


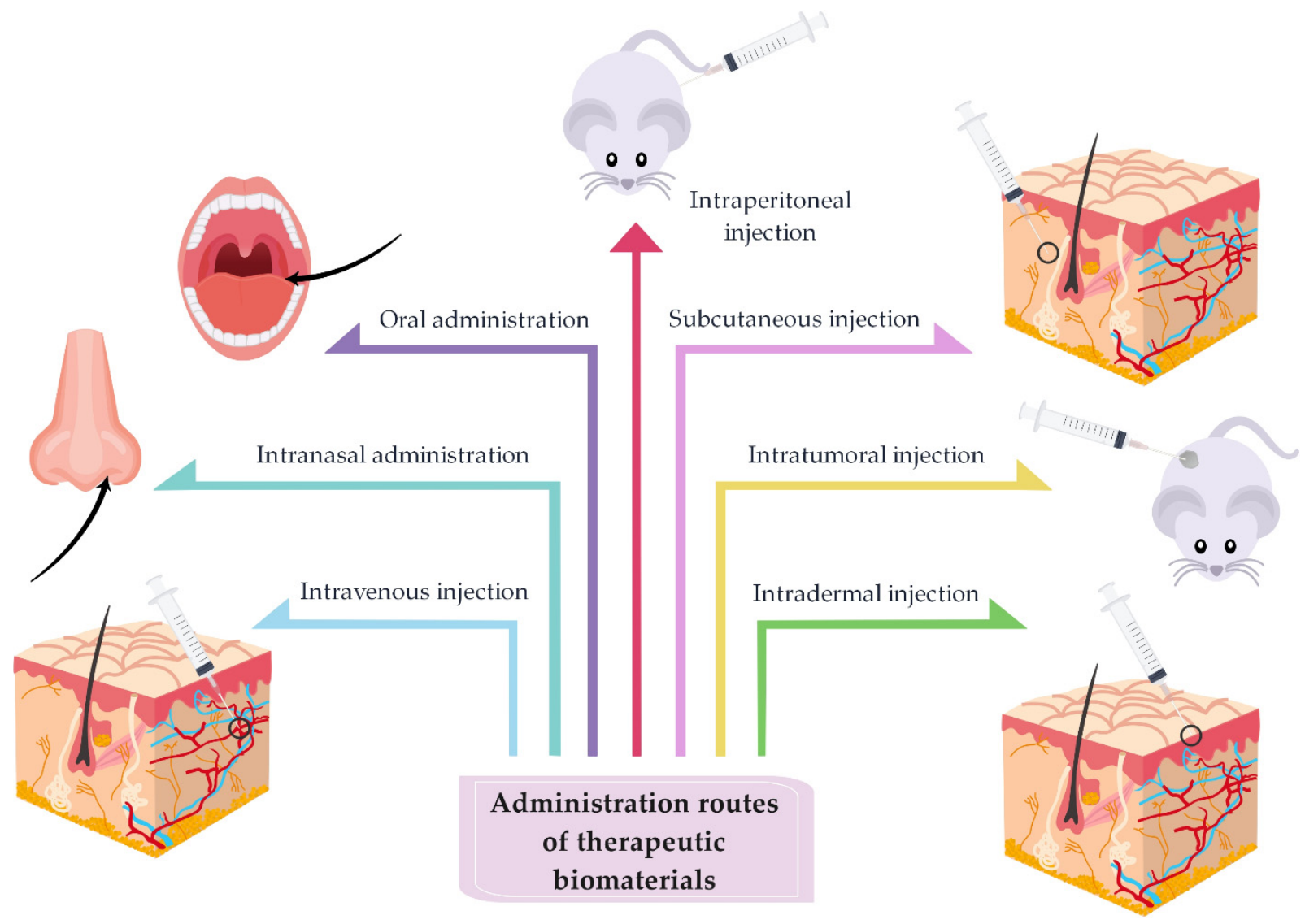

Figure 13. Representative structure of different administration routes of therapeutic biomaterials into the body through drug delivery: intravenous injection, intranasal administration, oral administration, intraperitoneal injection, subcutaneous injection, intratumoral injection, and intradermal injection (summarized from [2,11,102,147,173]).

\subsection{Drug Delivery through Intranasal Administration}

For the delivery of drugs to the central nervous system, the most effective way is through intranasal administration, that is, into the nose, as this avoids delivery through the blood-brain barrier [176]. Perets et al. [179] demonstrated that symptoms of autism spectrum disorders (ASD) were reduced in mice with intranasal administration of exosomes secreted from human BM-MSCs. There was an improvement in mutual interaction and a reduction in repetitive behavior, and no adverse effects were observed. Thus, exosomes may be used to treat ASD symptoms. Exosomes from MSCs have a neuroprotective effect, as they prevented perinatal brain injury through intranasal administration in mice [180].

\subsection{Drug Delivery through Subcutaneous Injection}

Subcutaneous injection, administrated beneath the skin, is effective in cutaneous malignancies and wound healing [173]. To treat MRSA infection, Yang et al. [110] used subcutaneous injection to deliver exosomes with an incorporated synthetic antibiotic to infected cells, and this proved to be an effective administration route. Gyeonghui et al. [181] injected exosomes obtained from different sources (RAW264.7 macrophage cell line, human serum, and fetal bovine serum) through subcutaneous administration into mice. Serum-derived exosomes incorporated with immune-stimulating biomolecules, such as CpG oligodeoxynucleotides (CpG ODN) and monophosphoryl lipid A (MPLA), have been shown to have exceptional properties as drug and immune stimulator carriers to the lymph nodes. After subcutaneous administration of exosomes with incorporated MLPA, activation and differentiation of $\mathrm{T}$ cells occurred, thereby increasing the cytokine IFN- $\gamma$ and TNF- $\alpha$ induction for CD3+T cells. Therefore, MLPA-incorporated exosomes are significantly influential in achieving the desired immune responses. 


\subsection{Drug Delivery through Intratumoral Injection}

In intratumoral administration, exosomes with incorporated drugs or therapeutic agents are injected directly into tumors. This causes degenerative changes in the tumor cells, thereby effectively reducing the size of the tumor [147]. By intratumoral administration of exosomes containing natural hyaluronidase $\mathrm{PH} 20$ and incorporated chemotherapeutic doxorubicin in mice with prostate cancer, effective inhibition of tumor growth due to increased exosome penetration and drug diffusion was achieved [182].

\subsection{Drug Delivery through Intradermal Administration}

Another one of the routes of exosome administration into the body is intradermal injection, which is achieved by injecting exosomes into the dermis. Morishita et al. [183] isolated exosomes from genetically engineered murine melanoma B16BL6 tumor cells that express the fusion protein streptavidin and lactadherin. They were then further modified with biotinylated immunostimulatory CpG DNA by streptavidin-biotin interaction. The exosomes prepared in this way were injected intradermally into mice, and the results showed successful antitumor effects.

\subsection{Drug Delivery through Intraperitoneal Injection}

Different routes of administration result in a different distribution of therapeutic biomaterials. Therefore, for optimal delivery of drugs to different organs, the appropriate choice of administration route is important. For example, exosomes were successfully delivered to the liver, spleen, and lungs by intravenous injection. In contrast, exosomes were more dispersedly distributed by intraperitoneal injection and, in addition to the liver, spleen, and lungs, effectively reached visceral adipose tissue. As a result, the administration of exosomes through intraperitoneal injection, administrated within the peritoneal cavity, has the potential to be used in the treatment of obesity [184].

Different administration routes of therapeutic biomaterials, including their therapeutic effects, are shown in Table 4.

Table 4. Drug delivery through different administration routes for various therapeutic purposes.

\begin{tabular}{|c|c|c|c|c|c|c|}
\hline $\begin{array}{l}\text { Source of } \\
\text { Therapeutic } \\
\text { Biomaterial }\end{array}$ & $\begin{array}{l}\text { Incorporated } \\
\text { Therapeutic } \\
\text { Compound }\end{array}$ & Target & $\begin{array}{l}\text { Administration } \\
\text { Route }\end{array}$ & Disease/Condition & Therapeutic Effect & Ref. \\
\hline \multirow[b]{2}{*}{ BM-MSCs } & - & Brain cells & Intranasal & $\begin{array}{l}\text { Autism spectrum } \\
\text { disorders (ASD) }\end{array}$ & Reduced symptoms of ASD & [179] \\
\hline & $\begin{array}{l}\text { Galectin-9 siRNA } \\
\text { and oxaliplatin }\end{array}$ & PANC-02 cells & Intravenous & $\begin{array}{l}\text { Pancreatic ductal } \\
\text { adenocarcinoma } \\
\text { (PDAC) }\end{array}$ & Antitumor efficacy & [83] \\
\hline $\begin{array}{l}\text { BM-MSCs from } \\
\text { mice }\end{array}$ & $\begin{array}{l}\mathrm{c}(\mathrm{RGDyK}) \\
\text { peptide and } \\
\text { curcumin }\end{array}$ & $\begin{array}{l}\text { Lesion region of } \\
\text { the ischemic } \\
\text { brain-microglia, } \\
\text { neurons, and } \\
\text { astrocytes }\end{array}$ & Intravenous & Cerebral ischemia & $\begin{array}{l}\text { Suppression of the } \\
\text { inflammatory response and } \\
\text { cellular apoptosis }\end{array}$ & [90] \\
\hline $\begin{array}{l}\text { Human adipose } \\
\text { tissue-derived } \\
\text { MSCs }\end{array}$ & - & Skin lesions & $\begin{array}{l}\text { Intravenous } \\
\text { Subcutaneous }\end{array}$ & $\begin{array}{l}\text { Atopic dermatitis } \\
\text { (AD) }\end{array}$ & $\begin{array}{l}\text { Reduced pathological } \\
\text { symptoms }\end{array}$ & [175] \\
\hline $\begin{array}{l}\text { Adipose-derived } \\
\text { stem cells (ASC) }\end{array}$ & - & Glial cells & $\begin{array}{l}\text { Intravenous } \\
\text { Intranasal }\end{array}$ & $\begin{array}{l}\text { Amyotrophic } \\
\text { lateral sclerosis } \\
\text { (ALS) }\end{array}$ & $\begin{array}{l}\text { Improvement of motor } \\
\text { performance; protective effect } \\
\text { on lumbar motoneurons, } \\
\text { neuromuscular junction and } \\
\text { muscle, reduction in glial } \\
\text { cells activation }\end{array}$ & [185] \\
\hline $\begin{array}{l}\text { Genetically } \\
\text { modified dental } \\
\text { pulp MSCs } \\
\text { (DPSCs) }\end{array}$ & $\begin{array}{c}\text { Tumor suppressor } \\
\text { miR-34a }\end{array}$ & $\begin{array}{l}\text { Breast carcinoma } \\
\text { cells }\end{array}$ & In Vitro & Breast cancer & Anticancer effects & [151] \\
\hline
\end{tabular}


Table 4. Cont

\begin{tabular}{|c|c|c|c|c|c|c|}
\hline $\begin{array}{l}\text { Source of } \\
\text { Therapeutic } \\
\text { Biomaterial }\end{array}$ & $\begin{array}{l}\text { Incorporated } \\
\text { Therapeutic } \\
\text { Compound }\end{array}$ & Target & $\begin{array}{l}\text { Administration } \\
\text { Route }\end{array}$ & Disease/Condition & Therapeutic Effect & Ref. \\
\hline \multirow{4}{*}{ Bovine milk } & siRNA & Lung cancer cells & Oral & Lung cancer & Antitumor efficacy & [116] \\
\hline & hsa-miR148a- & $\begin{array}{l}\text { Hepatic (HepG2) } \\
\text { and intestinal } \\
\text { (Caco-2) human } \\
\text { cell lines }\end{array}$ & In Vitro & $\begin{array}{l}\text { RNA-based } \\
\text { therapy }\end{array}$ & $\begin{array}{l}\text { Cost-effective source of } \\
\text { exosome as nanocarriers }\end{array}$ & [186] \\
\hline & Paclitaxel & Lung cancer cells & Oral & Lung cancer & Tumor growth inhibition & [177] \\
\hline & Curcumin & $\begin{array}{l}\text { Cervical cancer } \\
\text { cells }\end{array}$ & Oral & $\begin{array}{l}\text { Human cervical } \\
\text { cancer }\end{array}$ & Antitumor activity & [187] \\
\hline Bovine serum & $\alpha$-d-mannose & Lymph nodes & Intradermal & Immunotherapy & $\begin{array}{l}\text { Efficient delivery of immune } \\
\text { stimulators and antigens }\end{array}$ & [188] \\
\hline $\begin{array}{c}\text { Human } \\
\text { cardiac-resident } \\
\text { mesenchymal } \\
\text { progenitor cells } \\
\text { (CPCs) }\end{array}$ & - & Cardiomyocytes & Intravenous & Cardiac toxicity & $\begin{array}{l}\text { Inhibition of oxidative stress, } \\
\text { prevention of myocardial } \\
\text { fibrosis, inhibition of } \\
\text { cell death }\end{array}$ & [189] \\
\hline $\begin{array}{l}\text { Human } \\
\text { Wharton's jelly } \\
\text { MSC }\end{array}$ & Infrared-label & $\begin{array}{l}\text { Corpus callosum, } \\
\text { external capsule }\end{array}$ & Intranasal & $\begin{array}{l}\text { Perinatal brain } \\
\text { injury (PBI) }\end{array}$ & Neuroprotective effects & [180] \\
\hline Macrophage & $\begin{array}{l}\text { PLGA } \\
\text { nanoparticles, } \\
\text { loaded with } \\
\text { doxorubicin }\end{array}$ & Tumor cells & Intravenous & $\begin{array}{l}\text { Triple-negative } \\
\text { breast cancer } \\
\text { (TNBC) }\end{array}$ & $\begin{array}{l}\text { Improvement of the cellular } \\
\text { uptake efficiency and the } \\
\text { antitumor efficacy, remarkable } \\
\text { tumor-targeting efficacy, } \\
\text { increased inhibition of tumor } \\
\text { growth and induced intense } \\
\text { tumor apoptosis }\end{array}$ & [165] \\
\hline $\begin{array}{c}\text { Mouse RAW264.7 } \\
\text { macrophages }\end{array}$ & Linezolid & $\begin{array}{l}\text { MRSA WHO-2- } \\
\text { infected cells }\end{array}$ & Subcutaneous & MRSA infection & $\begin{array}{l}\text { Efficacious intracellular } \\
\text { antibiotic delivery }\end{array}$ & [110] \\
\hline $\begin{array}{c}\text { RAW264.7 } \\
\text { macrophage cell } \\
\text { line, mouse } \\
\text { serums, human } \\
\text { serums, and fetal } \\
\text { bovine serums }\end{array}$ & $\begin{array}{c}\text { CpG } \\
\text { oligodeoxynu- } \\
\text { cleotides (CpG } \\
\text { ODN), ovalbumin } \\
\text { (OVA), } \\
\text { monophosphoryl } \\
\text { lipid A (MPLA) } \\
\end{array}$ & $\begin{array}{l}\text { Macrophages in } \\
\text { lymph nodes }\end{array}$ & Subcutaneous & $\begin{array}{l}\text { Immune } \\
\text { stimulation }\end{array}$ & $\begin{array}{l}\text { Increased intracellular } \\
\text { delivery, potential immune } \\
\text { stimulation }\end{array}$ & [181] \\
\hline RAW264.7 cells & $\begin{array}{l}\text { Vancomycin and } \\
\text { lysostaphin }\end{array}$ & $\begin{array}{c}\text { MRSA } \\
\text { WHO-2-infected } \\
\text { cells }\end{array}$ & Intravenous & MRSA infection & $\begin{array}{l}\text { Efficient antibiotic delivery, } \\
\text { antibacterial efficiency }\end{array}$ & [84] \\
\hline $\begin{array}{l}\text { Mouse blood } \\
\text { reticulocytes }\end{array}$ & Dopamine & bEnd. 3 cells & Intravenous & $\begin{array}{l}\text { Parkinson's } \\
\text { disease }\end{array}$ & $\begin{array}{l}\text { Strong therapeutic efficacy, } \\
\text { reduced systemic toxicity }\end{array}$ & [174] \\
\hline HEK293T cell & Doxorubicin & $\begin{array}{l}\text { PC3 prostate } \\
\text { cancer cells }\end{array}$ & Intratumoral & Prostate cancer & $\begin{array}{l}\text { Efficient tumor } \\
\text { growth inhibition }\end{array}$ & [182] \\
\hline $\begin{array}{l}\text { Membrane } \\
\text { protein from red } \\
\text { blood cells and } \\
\text { MCF-7 } \\
\text { cancer cells }\end{array}$ & Doxorubicin & MCF-7 cells & Subcutaneous & Cancer & Anti-tumor therapeutic effect & [92] \\
\hline
\end{tabular}

Based on the properties of exosomes and the many studies already conducted both in vitro and in vivo, exosomes have shown the increasing potential for the development of new therapeutics. Many companies are already developing these, as shown in the following section.

\section{Commercial Therapeutic Biomaterials}

Various studies on exosomes have shown that they are non-toxic, even after repeated injections [190-192]. Therefore, exosomes are promising nanocarriers in the development of new therapeutic approaches to drug delivery and other therapeutic agents, due to their 
unique characteristics. Consequently, scientists from around the world are increasingly researching this field, and many commercial companies have successfully established various exosome platforms and produced therapeutic exosomes that are in pre-clinical studies, some of them already in Phase 1. These companies are listed in Table 5.

Table 5. Commercial companies using exosomes.

\begin{tabular}{|c|c|c|c|c|}
\hline Company Name & $\begin{array}{c}\text { Commercial } \\
\text { Exosome/Technology }\end{array}$ & Therapeutic Application & $\begin{array}{l}\text { Exosome Source and } \\
\text { Incorporated Cargo }\end{array}$ & Ref. \\
\hline Aegle Therapeutics & AGLE-102 & Serious dermatologic disorders & Allogeneic BM-MSCs & [193] \\
\hline Aethlon Medical, Inc. & Hemopurifier $^{\circledR}$ & Infectious disease and cancer & - & [194] \\
\hline Anjarium Biosciences & Hybridosome ${ }^{\circledR}$ platform & Cancer and genetic diseases & - & [195] \\
\hline Aruna Bio & $\begin{array}{c}\text { Neuronal exosome } \\
\text { platform: product AB126 }\end{array}$ & Neurological diseases & Neural stem cells & [196] \\
\hline Capricor Therapeutics & See Table 6. & Severe and rare disorders (i.e., DMD) & - & {$[197]$} \\
\hline Carmine Therapeutics & REGENT $^{\circledR}$ & Gene therapy & Red blood cells & \\
\hline Ciloa & $\begin{array}{l}\text { Vaccine candidates against } \\
\text { Chikungunya virus (FUI } \\
\text { granted) and Zika }\end{array}$ & Antibodies, vaccines, therapeutic vectors & Recombinant exosomes & [198] \\
\hline Clara Biotech & ExoRelease $^{\mathrm{TM}}$ & Exosome Isolation Platform & - & [199] \\
\hline Codiak Biosciences & $\begin{array}{l}\text { engEx }{ }^{\mathrm{TM}} \text { platform } \\
\text { (Products: see Table 7.) }\end{array}$ & $\begin{array}{l}\text { Cancer, neurological diseases, } \\
\text { vaccine development }\end{array}$ & - & [200] \\
\hline Direct Biologics & $\mathrm{ExoFlo}^{\mathrm{TM}}$ & $\begin{array}{l}\text { Providing signaling proteins that modulate } \\
\text { inflammation }\end{array}$ & Human BM-MSCs & [201] \\
\hline Evox Therapeutics & $\begin{array}{l}\text { DeliverEX }{ }^{\mathrm{TM}} \text { platform } \\
\text { (Products: see Table 8.) }\end{array}$ & Severe rare genetic disorders & Drug-loaded exosomes & [202] \\
\hline EV Therapeutics Inc. & $\begin{array}{l}\text { mTEV platform (EV101, } \\
\text { EV102, EV103) }\end{array}$ & $\begin{array}{l}\text { Gastrointestinal cancer, organ } \\
\text { transplant rejection }\end{array}$ & - & [203] \\
\hline Exocel Bio & EXOVEX & Regenerative medicine & - & [204] \\
\hline \multirow[t]{2}{*}{ ExoCoBio } & ExoSCRT $^{\mathrm{TM}}$ & $\begin{array}{l}\text { Isolation and purification technology, } \\
\text { technology for mass production of highly } \\
\text { efficient exosomes }\end{array}$ & \multirow[t]{2}{*}{ Stem cells } & \multirow[t]{2}{*}{ [205] } \\
\hline & $\begin{array}{l}\text { Therapeutic and cosmetic } \\
\text { products ASCE }\end{array}$ & $\begin{array}{l}\text { Regenerate or activate/de-activate various } \\
\text { tissues or cells }\end{array}$ & & \\
\hline \multirow{3}{*}{ Exopharm Pty Ltd. } & $\begin{array}{l}\text { Exopharm's LEAP } \\
\text { Technology }\end{array}$ & $\begin{array}{l}\text { Isolating and purifying exosomes from adult } \\
\text { stem cells }\end{array}$ & Stem cells & \multirow{3}{*}{ [206] } \\
\hline & $\begin{array}{l}\text { Engineering exosomes } \\
\text { (See Table 9.) }\end{array}$ & Antiviral, neurodegeneration, cancer & $\begin{array}{l}\text { Cargos: such as RNA, } \\
\text { enzymes and/or } \\
\text { small molecules }\end{array}$ & \\
\hline & $\begin{array}{l}\text { Natural exosomes } \\
\text { (See Table 9.) }\end{array}$ & Wound healing, osteoarthritis & $\begin{array}{l}\text { Adult stem cells } \\
\text { and platelets }\end{array}$ & \\
\hline Exosome Diagnostics & ExoDx ${ }^{\mathrm{TM}}$ Prostate test & $\begin{array}{l}\text { Diagnosis and assessment of the risk of } \\
\text { prostate cancer }\end{array}$ & - & [207] \\
\hline Exosome Sciences & TauSome $^{\mathrm{TM}}$ biomarker & $\begin{array}{l}\text { Diagnosis and monitoring of Alzheimer's } \\
\text { disease, chronic traumatic encephalopathy, and } \\
\text { other neurological disorders }\end{array}$ & - & [208] \\
\hline Exosomics Siena SpA & $\begin{array}{l}\text { Exosome-based } \\
\text { liquid biopsy }\end{array}$ & Exosome-based cancer screening and diagnosis & - & [209] \\
\hline Exogenus Therapeutics & Exo-101 & $\begin{array}{l}\text { Regenerative medicine and inflammatory } \\
\text { disorders (inflammatory skin conditions, } \\
\text { inflammatory lung disorders, chronic wounds) }\end{array}$ & $\begin{array}{l}\text { Umbilical cord blood } \\
\text { mononuclear cells }\end{array}$ & [210] \\
\hline \multirow{2}{*}{ Ilias Biologics Inc. } & $\begin{array}{l}\text { EXPLOR }{ }^{\mathrm{TM}} \text { platform } \\
\text { technology }\end{array}$ & $\begin{array}{l}\text { Loading of specific proteins into exosomes in a } \\
\text { controllable way }\end{array}$ & - & \multirow{2}{*}{ [211] } \\
\hline & Exo-Target $^{\circledR}$ & Inflammatory and metabolic diseases, cancers & $\begin{array}{l}\text { Therapeutic exosomes } \\
\text { loaded with API molecule }\end{array}$ & \\
\hline Kimera Labs & XoGlo $^{\circledR}$ & $\begin{array}{l}\text { Wound healing and skin } \\
\text { rejuvenation/regeneration }\end{array}$ & MSCs & {$[212]$} \\
\hline
\end{tabular}


Table 5. Cont.

\begin{tabular}{|c|c|c|c|c|}
\hline Company Name & $\begin{array}{c}\text { Commercial } \\
\text { Exosome/Technology }\end{array}$ & Therapeutic Application & $\begin{array}{l}\text { Exosome Source and } \\
\text { Incorporated Cargo }\end{array}$ & Ref. \\
\hline OmniSpirant & $\begin{array}{l}\text { Inhaled exosome } \\
\text { technology platform }\end{array}$ & $\begin{array}{l}\text { Currently incurable respiratory diseases, } \\
\text { cystic fibrosis }\end{array}$ & Bioengineered stem cells & [213] \\
\hline Paracrine Therapeutics & $\begin{array}{l}\text { Exosome Technology } \\
\text { Platform }\end{array}$ & Regenerative medicine & Stem cells & \\
\hline ReNeuron & ExoPr0 & $\begin{array}{l}\text { Neurodegenerative diseases, cancer, } \\
\text { development of vaccines }\end{array}$ & CTX neural stem cells & [214] \\
\hline Stem Cell Medicine Ltd. & $\begin{array}{l}\text { Exosome-based } \\
\text { technology }\end{array}$ & $\begin{array}{l}\text { Neurodegenerative and neuropsychiatric } \\
\text { indications: autism spectrum disorder (ASD) }\end{array}$ & Adult stem cells & [215] \\
\hline TAVEC Pharmaceuticals & miRNA-loaded exosomes & Anti-cancer gene therapy & - & [216] \\
\hline \multirow{2}{*}{ XOStem Inc. } & XO-Regen ${ }^{\circledR}$ & $\begin{array}{l}\text { Articular damage, respiratory } \\
\text { failure, neuroinflammation }\end{array}$ & \multirow{2}{*}{$\begin{array}{l}\text { Bone marrow and } \\
\text { umbilical cord } \\
\text { derived MSCs }\end{array}$} & \multirow{2}{*}{ [217] } \\
\hline & XO-Cutis ${ }^{\circledR}$ & $\begin{array}{l}\text { Hair regeneration, skin rejuvenation, } \\
\text { wound healing }\end{array}$ & & \\
\hline
\end{tabular}

Table 6. Promising therapeutic candidates from Capricor Therapeutics [197].

\begin{tabular}{ccc}
\hline Therapeutic Candidate & Purpose & Development Phase \\
\hline $\begin{array}{c}\text { Exosome mRNA Vaccine } \\
\text { (Tripartite mRNA design) }\end{array}$ & SARS-CoV-2 & Preclinical \\
\hline $\begin{array}{c}\text { Exosome VLP Display Vaccine } \\
\text { (4-part antigen design) }\end{array}$ & SARS-CoV-2 & Preclinical \\
\hline $\begin{array}{c}\text { CDC-Exosomes } \\
\text { (allogenic cardiosphere-derived cells (CDC)-exosomes) }\end{array}$ & DMD & Phase 1 \\
\hline $\begin{array}{c}\text { Engineered Exosomes } \\
\text { (RNA delivery) }\end{array}$ & Evaluating & Discovery \\
\hline $\begin{array}{c}\text { ASTEX-Exosomes } \\
\text { (engineered fibroblast-derived exosomes) }\end{array}$ & Evaluating & Discovery \\
\hline
\end{tabular}

Table 7. Exploring engEx therapeutic candidates from Codiak Biosciences [200].

\begin{tabular}{|c|c|c|c|c|}
\hline Field & Therapeutic Candidate & Purpose & $\underset{\text { Route }}{\text { Administration }}$ & $\begin{array}{l}\text { Development } \\
\text { Phase }\end{array}$ \\
\hline \multirow{7}{*}{ Oncology } & exoIL-12 ${ }^{\mathrm{TM}}$ & $\begin{array}{c}\text { Cutaneous T-cell lymphoma (CTCL), } \\
\text { Melanoma, } \\
\text { Triple-negative breast cancer (TNBC), } \\
\text { Merkel cell carcinoma (MCC), } \\
\text { Kaposi's sarcoma, } \\
\text { Glioblastoma multiforme (GBM) }\end{array}$ & Intratumoral & Phase 1 \\
\hline & exoSTING ${ }^{\mathrm{TM}}$ & $\begin{array}{c}\text { Solid tumors, i.e.,: } \\
\text { Head and neck squamous cell Carcinoma (HNSCC), } \\
\text { TNBC, } \\
\text { Anaplastic thyroid cancer (ATC), } \\
\text { Cutaneous squamous cell carcinoma (cSCC) }\end{array}$ & Intratumoral & Phase 1 \\
\hline & exoSTING ${ }^{\mathrm{TM}}$ & $\begin{array}{c}\text { GMB, } \\
\text { Leptomeningeal cancer (LMD) }\end{array}$ & $\begin{array}{c}\text { Intratumoral, } \\
\text { intratheca }\end{array}$ & Preclinical \\
\hline & exoASO ${ }^{\text {TM_STAT6 }}$ & $\begin{array}{c}\text { Myeloid rich cancers, i.e.,: } \\
\text { Hepatocellular carcinoma (HCC), } \\
\text { Pancreatic ductal adenocarcinoma (PDAC), } \\
\text { Colorectal cancer (CRC) } \\
\text { Ovarian cancer }\end{array}$ & Intratumoral & Preclinical \\
\hline & exoASO ${ }^{\text {TM_STAT3 }}$ & Hematologic/hepatic cancers & TBD & Preclinical \\
\hline & exoASO ${ }^{\text {TM}}$-NRAS & Hematologic cancers/solid tumors & TBD & Discovery \\
\hline & Oncogene Targets & Hematologic cancers/solid tumors & TBD & Discovery \\
\hline \multirow{3}{*}{ Neurology } & exoASO-NLRP3 & Neuroinflammation & Intrathecal & Discovery \\
\hline & exoASO $^{\mathrm{TM}}-\mathrm{NLRP3}$ & Neuropathy & Intrathecal & Discovery \\
\hline & Gene Targets & Neuromuscular diseases & TBD & Discovery \\
\hline Vaccines & exoVACC ${ }^{\mathrm{TM}}$ & Cancers, neurodegenerative diseases, viral diseases & TBD & Discovery \\
\hline
\end{tabular}


Table 8. Exosome-based therapeutics from Evox Therapeutics [202].

\begin{tabular}{|c|c|c|c|c|}
\hline Field & Therapeutic Product & Purpose & Cargo & Development Phase \\
\hline \multirow{2}{*}{ Urea cycle disorders } & EVX-102 & ASA & Protein exosomes & Pre-clinical \\
\hline & EVX-103 & Citrullinemia type I & Protein exosomes & Discovery \\
\hline Rare metabolic & - & PKU & Undisclosed modality & Discovery \\
\hline
\end{tabular}

Table 9. Therapeutic products from Exopharm Pty Ltd. [206].

\begin{tabular}{cccc}
\hline Exosome Type & Therapeutic Product & Purpose & Development Phase \\
\hline \multirow{2}{*}{ Natural exosomes } & Plexaris & Wound healing & Phase 1 \\
\cline { 2 - 4 } & Cevaris & Osteoarthritis & Pre-clinical \\
\cline { 2 - 4 } Engineering exosomes & Fortrexo & Antiviral & Pre-clinical \\
\cline { 2 - 4 } & Cognevo & Neurodegeneration & Discovery \\
\cline { 2 - 4 } & PlexoDOX & Cancer & Discovery \\
\hline
\end{tabular}

A detailed description of some of the most important companies mentioned above is given below.

\subsection{Aegle Therapeutics}

Aegle Therapeutics is a biotechnological company from Miami, Florida, USA, and is the first for which human clinical testing for an exosome product has been approved by the U.S. Food and Drug Administration (FDA) for AGLE-102. Exosomes isolated from allogeneic BM-MSCs are used to treat dystrophic epidermolysis bullosa (DEB), i.e., a rare genetic pediatric connective tissue disorder, as well other serious dermatological disorders such as severe burns and wounds. Therapy can be performed by local injection or topically [193].

\subsection{Capricor Therapeutics}

Capricor Therapeutics is a clinical-stage biotechnology company from Beverly Hills, California, USA, and is one of the leading companies researching the field of exosomes. Researchers at Capricor Therapeutics are focused on developing and researching exosomebased therapeutics (Table 6) to treat and prevent severe and rare diseases and disorders, particularly Duchenne muscular dystrophy (DMD). They are also involved in the development of vaccines and the treatment of inherited diseases. One of them is already in Phase 1 development [197].

\subsection{Codiak Biosciences}

Codiak Biosciences from Cambridge, United Kingdom, has developed the engEx platform, which enables the production of exosomes with different properties, loaded with various therapeutic agents, and the ability to reach the desired target cells. They are developing various promising therapeutic exosomes based on engEx for the treatment of different types of cancer, neurological diseases and for vaccine development, as shown in Table 7. Two of these (exoIL-12 ${ }^{\mathrm{TM}}$ and exoSTING ${ }^{\mathrm{TM}}$ ) are already in Phase 1 development, which began in September 2020 [200].

\subsection{Evox Therapeutics}

Evox Therapeutics is a company from Oxford, United Kingdom, that has developed the DeliverEX ${ }^{\mathrm{TM}}$ platform, designed for the development of exosome-based therapeutics for the treatment of rare, life-threatening diseases. They appropriately modify exosomes, incorporated with drugs, to deliver these drugs to target organs to treat severe rare genetic 
disorders, including argininosuccinic aciduria (ASA), Citrullinemia type I, and phenylketonuria (PKU) [202]. They have already developed a few products, as shown in Table 8.

\subsection{Exogenus Therapeutics}

Exogenus Therapeutics is a Portuguese company and a pioneer in the development of exosome-based therapeutics. For their leading candidate, Exo-101, they have demonstrated in vitro and in vivo regenerative, anti-inflammatory, and immunomodulatory properties. Additional research is focused on the potential treatment of inflammatory skin diseases, such as psoriasis, and helping patients with inflammatory lung diseases, including COVID19 patients with respiratory complications, and it has already been shown to accelerate the healing of chronic wounds. Exo-101 are isolated by an optimized process combining ultracentrifugation and size-exclusion pooling chromatography from umbilical cord blood mononuclear cells. They have also developed ExoWound, a combination of Exo-101 with a slow-release hydrogel that has potential for treating chronic wounds as it hardens at body temperature [210].

\subsection{Anjarium Biosciences}

Anjarium Biosciences is a company from Switzerland. They developed the Hybridosome ${ }^{\circledR}$ platform for engineering exosome-based therapeutics production for the effective treatment and prevention of cancer and genetic diseases. In the development of engineering exosomes, they focus on both cargo incorporation and surface modifications to treat diseases for which current approaches are ineffective. Their focus is mainly on therapeutic RNA as the cargo. The product AB126 is both a therapeutic agent and a delivery vehicle to the central nervous system (CNS) to treat a variety of neurodegenerative diseases, such as Parkinson's disease and multiple sclerosis, as well as for stroke, for which it is already in the preclinical phase [195].

\subsection{Aruna Bio}

Aruna Bio is a Greek company which in the past focused on the production of neural stem cells, but today mainly focuses on cell-free biological therapeutics, i.e., neuronal exosomes isolated from neuronal stem cells. They are developing a completely new platform - a neuronal exosome platform to deliver drugs as a new and effective way of treating neurodegenerative diseases. Their neuronal exosomes successfully target cells in the CNS, and in preclinical studies they have successfully achieved their crossing of the blood-brain barrier [196].

\subsection{ReNeuron}

ReNeuron is a company from the United Kingdom and is a leader in the field of clinical-stage stem cells. In addition to developing new stem cell therapies, they have also developed a new product, i.e., a therapeutic candidate, called ExoPr0, produced from CTX neural stem cells, which is a successful delivery vehicle as already proven in preclinical studies. It was developed for the treatment of neurodegenerative diseases, cancer, and for the development of vaccines such as COVID-19 [214].

\subsection{Exopharm Pty Ltd.}

Exopharm is an Australian clinical-stage company that develops exosome-based therapeutics. They are developing engineering exosomes for drug delivery in the treatment of infectious diseases, neurological diseases, and cancer, and natural exosomes, produced from stem cells and platelets, suitable for the treatment of osteoarthritis, chronic and acute injuries. Several products have already been developed (Table 9), some are in preclinical studies, and Plexaris ${ }^{\mathrm{TM}}$ is already in Phase 1 [206]. 


\subsection{ExoCoBio}

ExoCoBio is a company from Seul, South Korea, and is one of the world's leading companies in the production of exosome-based biomedical and regenerative therapeutics. They have patented technology for isolating and purifying exosomes from stem cells, technology for mass-production of highly efficient exosomes suitable for biomedical purposes, as well as optimized technology for regenerative medicine (ExoSCRT ${ }^{\mathrm{TM}}$ ). Their focus is on the development of therapeutics for the treatment of atopic dermatitis, inflammatory bowel disease, acute kidney injury, and alopecia (hair loss), as well as for immuno-oncology treatment. They have also developed their line of exosome-based cosmetics Advanced Skincare Complex for Everyone (ASCE), and a cosmetic ingredient, hybrid exosome Vexosome ${ }^{\mathrm{TM}}$ [205].

\section{Conclusions and Future Perspectives}

Exosomes have received a lot of attention over the last two decades, due to their unique characteristics, biocompatibility and safety, remaining stable through digestive and other biological fluids, and able to cross the blood-brain barrier. They are secreted by many different cells, and researchers have mainly focused on human, animal, and plant-derived exosomes. They are promising for use as biomarkers and in gene therapy, tissue regeneration, and vaccine development, and especially as delivery vehicles of drugs and other therapeutic agents. Extremely successful therapeutic effects of exosomes isolated from a variety of cells have been demonstrated in various studies in animal models.

By modifying naturally isolated exosomes, the most suitable nanocarriers can be prepared for the specific purpose of treatment and delivery of the desired therapeutic agents. The surface of exosomes can be modified to reach the recipient cells successfully and to enable an easy uptake into the cells. The desired components with therapeutic properties can be encapsulated into exosomes, which would not reach the target cells in such a high concentration without appropriate nanocarriers. However, it is also important to emphasize that these approaches must ensure that the structure and functions of isolated exosomes do not change significantly. Different methods can be used for exosome preparation. Knowing the advantages and disadvantages of individual methods of exosome production and preparation, which are also presented in detail in this review article, can greatly contribute to the selection of the most appropriate method for the synthesis of the desired exosomes. Further, new approaches have been developed for fully synthetic exosome production that mimics the characteristics of natural exosomes and could have more specific target properties, although these have not yet been explored to such an extent as modified exosomes.

Current drugs and treatments for cancer can cause side effects, cytotoxicity, and longterm complications, and can also quickly lead to drug resistance in treated patients. As a result, exosomes are of great importance in the development of treatments for various types of cancer, as anti-tumor therapeutic efficacy has been successfully demonstrated in various in vitro and in vivo studies in animal models. They have also shown great potential as drug carriers for the possible treatment of various neurodegenerative and cardiovascular diseases and are effective in delivering antibiotics to pathogen-infected cells and thus have antibacterial activity.

Therapeutic biomaterials have recently played a particularly important role in the development of vaccines, especially for cell-free vaccines, which can be successfully achieved with the use of exosomes. A few global commercial companies (Aethlon Medical, Inc., Capricor Therapeutics, and ReNeuron), on which a detailed review was done for the first time in this work, are already developing vaccines that have potential for treating SARS-CoV-2 infections, but these are still only in the development phase.

Despite many successful studies, there are still many challenges to be overcome before exosome-based therapeutics can be used, as more clinical studies are needed. However, many companies have already developed appropriate exosome platforms and exosome products that are approaching clinical trial approvals or are already in Phase 1. Therefore, 
extremely successful drug delivery and effective treatment of various serious disease conditions can be achieved through the use of therapeutic biomaterials, i.e., exosomes, with these being highly promising approaches thar are likely to be increasingly important in the future.

Author Contributions: N.K. and M.L. conceived and designed the article. N.K. studied the literature and wrote the manuscript. M.P. and M.L. reviewed and edited the article. Ž.K. was responsible for the financial part of the project. All authors have read and agreed to the published version of the manuscript.

Funding: This research was supported by the Slovenian Research Agency (ARRS) within the frame of program P2-0046 (Separation Processes and Production Design) and project No. J2-1725 (Smart materials for bioapplications).

Conflicts of Interest: The authors declare no conflict of interest.

\section{References}

1. Sur, S.; Rathore, A.; Dave, V.; Reddy, K.R.; Chouhan, R.S.; Sadhu, V. Recent Developments in Functionalized Polymer Nanoparticles for Efficient Drug Delivery System. Nano-Struct. Nano-Objects 2019, 20, 100397. [CrossRef]

2. Begines, B.; Ortiz, T.; Pérez-Aranda Redondo, M.; Martínez, G.; Merinero de Los Santos, M.; Arias, F.; Alcudia, A. Polymeric Nanoparticles for Drug Delivery: Recent Developments and Future Prospects. Nanomaterials 2020, 10, 1403. [CrossRef]

3. Li, C.; Wang, J.; Wang, Y.; Gao, H.; Wei, G.; Huang, Y.; Yu, H.; Gan, Y.; Wang, Y.; Mei, L.; et al. Recent Progress in Drug Delivery. Acta Pharm. Sin. B 2019, 9, 1145-1162. [CrossRef] [PubMed]

4. Lombardo, D.; Kiselev, M.; Caccamo, M.T. Smart Nanoparticles for Drug Delivery Application: Development of Versatile Nanocarrier Platforms in Biotechnology and Nanomedicine. J. Nanomater. 2019, 2019, 3702518. [CrossRef]

5. Yu, X.; Trase, I.; Ren, M.; Duval, K.; Guo, X.; Chen, Z. Design of Nanoparticle-Based Carriers for Targeted Drug Delivery. J. Nanomater. 2016, 2016, 1087250. [CrossRef] [PubMed]

6. El-Say, K.M.; El-Sawy, H.S. Polymeric Nanoparticles: Promising Platform for Drug Delivery. Int. J. Pharm. 2017, 528, 675-691. [CrossRef]

7. Luan, X.; Sansanaphongpricha, K.; Myers, I.; Chen, H.; Yuan, H.; Sun, D. Engineering Exosomes as Refined Biological Nanoplatforms for Drug Delivery. Acta Pharmacol. Sin. 2017, 38, 754-763. [CrossRef]

8. Akuma, P.; Okagu, O.D.; Udenigwe, C.C. Naturally Occurring Exosome Vesicles as Potential Delivery Vehicle for Bioactive Compounds. Front. Sustain. Food Syst. 2019, 3, 23. [CrossRef]

9. Lu, M.; Huang, Y. Bioinspired Exosome-like Therapeutics and Delivery Nanoplatforms. Biomaterials 2020, 242, 119925. [CrossRef]

10. Farooqi, A.A.; Desai, N.N.; Qureshi, M.Z.; Librelotto, D.R.N.; Gasparri, M.L.; Bishayee, A.; Nabavi, S.M.; Curti, V.; Daglia, M. Exosome Biogenesis, Bioactivities and Functions as New Delivery Systems of Natural Compounds. Biotechnol. Adv. 2018, 36, 328-334. [CrossRef]

11. Zhang, Y.; Bi, J.; Huang, J.; Tang, Y.; Du, S.; Li, P. Exosome: A Review of Its Classification, Isolation Techniques, Storage, Diagnostic and Targeted Therapy Applications. Int. J. Nanomed. 2020, 15, 6917-6934. [CrossRef] [PubMed]

12. Daßler-Plenker, J.; Küttner, V.; Egeblad, M. Communication in Tiny Packages: Exosomes as Means of Tumor-Stroma Communication. Biochim. Biophys. Acta Rev. Cancer 2020, 1873, 188340. [CrossRef] [PubMed]

13. Sun, D.; Zhuang, X.; Zhang, S.; Deng, Z.-B.; Grizzle, W.; Miller, D.; Zhang, H.-G. Exosomes Are Endogenous Nanoparticles That Can Deliver Biological Information between Cells. Adv. Drug Deliv. Rev. 2013, 65, 342-347. [CrossRef]

14. Villata, S.; Canta, M.; Cauda, V. EVs and Bioengineering: From Cellular Products to Engineered Nanomachines. Int. J. Mol. Sci. 2020, 21, 6048. [CrossRef] [PubMed]

15. Jafari, D.; Shajari, S.; Jafari, R.; Mardi, N.; Gomari, H.; Ganji, F.; Forouzandeh Moghadam, M.; Samadikuchaksaraei, A. Designer Exosomes: A New Platform for Biotechnology Therapeutics. BioDrugs 2020, 34, 567-586. [CrossRef]

16. Antimisiaris, S.G.; Mourtas, S.; Marazioti, A. Exosomes and Exosome-Inspired Vesicles for Targeted Drug Delivery. Pharmaceutics 2018, 10, 218. [CrossRef]

17. Li, S.; Lin, Z.; Jiang, X.; Yu, X. Exosomal Cargo-Loading and Synthetic Exosome-Mimics as Potential Therapeutic Tools. Acta Pharmacol. Sin. 2018, 39, 542-551. [CrossRef]

18. García-Manrique, P.; Matos, M.; Gutiérrez, G.; Pazos, C.; Blanco-López, M.C. Therapeutic Biomaterials Based on Extracellular Vesicles: Classification of Bio-Engineering and Mimetic Preparation Routes. J. Extracell Vesicles 2018, 7, 1422676. [CrossRef] [PubMed]

19. Leggio, L.; Arrabito, G.; Ferrara, V.; Vivarelli, S.; Paternò, G.; Marchetti, B.; Pignataro, B.; Iraci, N. Mastering the Tools: Natural versus Artificial Vesicles in Nanomedicine. Adv. Healthc. Mater. 2020, 9, e2000731. [CrossRef]

20. García-Manrique, P.; Gutiérrez, G.; Blanco-López, M.C. Fully Artificial Exosomes: Towards New Theranostic Biomaterials. Trends Biotechnol. 2018, 36, 10-14. [CrossRef]

21. Doyle, L.M.; Wang, M.Z. Overview of Extracellular Vesicles, Their Origin, Composition, Purpose, and Methods for Exosome Isolation and Analysis. Cells 2019, 8, 727. [CrossRef] 
22. Tran, P.H.L.; Xiang, D.; Tran, T.T.D.; Yin, W.; Zhang, Y.; Kong, L.; Chen, K.; Sun, M.; Li, Y.; Hou, Y.; et al. Exosomes and Nanoengineering: A Match Made for Precision Therapeutics. Adv. Mater. 2020, 32, 1904040. [CrossRef] [PubMed]

23. Conlan, R.S.; Pisano, S.; Oliveira, M.I.; Ferrari, M.; Pinto, I.M. Exosomes as Reconfigurable Therapeutic Systems. Trends Mol. Med. 2017, 23, 636-650. [CrossRef] [PubMed]

24. Ha, D.; Yang, N.; Nadithe, V. Exosomes as Therapeutic Drug Carriers and Delivery Vehicles across Biological Membranes: Current Perspectives and Future Challenges. Acta Pharm. Sin. B 2016, 6, 297-307. [CrossRef]

25. Agrahari, V.; Agrahari, V.; Burnouf, P.-A.; Chew, C.H.; Burnouf, T. Extracellular Microvesicles as New Industrial Therapeutic Frontiers. Trends Biotechnol. 2019, 37, 707-729. [CrossRef]

26. Battistelli, M.; Falcieri, E. Apoptotic Bodies: Particular Extracellular Vesicles Involved in Intercellular Communication. Biology 2020, 9, 21. [CrossRef] [PubMed]

27. Riazifar, M.; Pone, E.J.; Lötvall, J.; Zhao, W. Stem Cell Extracellular Vesicles: Extended Messages of Regeneration. Annu. Rev. Pharmacol. Toxicol. 2017, 57, 125-154. [CrossRef] [PubMed]

28. Atkin-Smith, G.; Paone, S.; Zanker, D.; Duan, M.; Phan, T.K.; Chen, W.; Hulett, M.; Poon, I. Isolation of Cell Type-Specific Apoptotic Bodies by Fluorescence-Activated Cell Sorting. Sci. Rep. 2017, 7, 39846. [CrossRef] [PubMed]

29. McBride, J.D.; Rodriguez-Menocal, L.; Badiavas, E.V. Extracellular Vesicles as Biomarkers and Therapeutics in Dermatology: A Focus on Exosomes. J. Investig. Dermatol. 2017, 137, 1622-1629. [CrossRef]

30. Zhang, H.; Freitas, D.; Kim, H.S.; Fabijanic, K.; Li, Z.; Chen, H.; Mark, M.T.; Molina, H.; Martin, A.B.; Bojmar, L.; et al. Identification of Distinct Nanoparticles and Subsets of Extracellular Vesicles by Asymmetric Flow Field-Flow Fractionation. Nat. Cell Biol. 2018, 20, 332-343. [CrossRef]

31. Willms, E.; Johansson, H.; Mäger, I.; Lee, Y.X.F.; Blomberg, K.E.; Sadik, M.; Alaarg, A.; Smith, E.; Lehtiö, J.; Andaloussi, S.; et al. Cells Release Subpopulations of Exosomes with Distinct Molecular and Biological Properties. Sci. Rep. 2016, 6, 22519. [CrossRef]

32. Mashouri, L.; Yousefi, H.; Aref, A.R.; Ahadi, A.m.; Molaei, F.; Alahari, S.K. Exosomes: Composition, Biogenesis, and Mechanisms in Cancer Metastasis and Drug Resistance. Mol. Cancer 2019, 18, 75. [CrossRef]

33. Skotland, T.; Sandvig, K.; Llorente, A. Lipids in Exosomes: Current Knowledge and the Way Forward. Prog. Lipid Res. 2017, 66, 30-41. [CrossRef] [PubMed]

34. Geis-Asteggiante, L.; Belew, A.T.; Clements, V.K.; Edwards, N.J.; Ostrand-Rosenberg, S.; El-Sayed, N.M.; Fenselau, C. Differential Content of Proteins, MRNAs, and MiRNAs Suggests That MDSC and Their Exosomes May Mediate Distinct Immune Suppressive Functions. J. Proteome Res. 2018, 17, 486-498. [CrossRef]

35. Di, C.; Zhang, Q.; Wang, Y.; Wang, F.; Chen, Y.; Gan, L.; Zhou, R.; Sun, C.; Li, H.; Zhang, X.; et al. Exosomes as Drug Carriers for Clinical Application. Artif. Cells Nanomed. Biotechnol. 2018, 46, S564-S570. [CrossRef]

36. Leone, D.A.; Rees, A.J.; Kain, R. Dendritic Cells and Routing Cargo into Exosomes. Immunol. Cell Biol. 2018, 96, 683-693. [CrossRef]

37. Crenshaw, B.J.; Sims, B.; Matthews, Q.L. Biological Function of Exosomes as Diagnostic Markers and Therapeutic Delivery Vehicles in Carcinogenesis and Infectious Diseases. In Nanomedicines; Intechopen: London, UK, 2018. [CrossRef]

38. Martinez-Arroyo, O.; Ortega, A.; Redon, J.; Cortes, R. Therapeutic Potential of Extracellular Vesicles in Hypertension-Associated Kidney Disease. Hypertension 2021, 77, 28-38. [CrossRef] [PubMed]

39. Wu, S.-C.; Kuo, P.-J.; Rau, C.-S.; Wu, Y.-C.; Wu, C.-J.; Lu, T.-H.; Lin, C.-W.; Tsai, C.-W.; Hsieh, C.-H. Subpopulations of Exosomes Purified via Different Exosomal Markers Carry Different MicroRNA Contents. Int. J. Med. Sci. 2021, 18, 1058-1066. [CrossRef] [PubMed]

40. Wu, D.; Yan, J.; Shen, X.; Sun, Y.; Thulin, M.; Cai, Y.; Wik, L.; Shen, Q.; Oelrich, J.; Qian, X.; et al. Profiling Surface Proteins on Individual Exosomes Using a Proximity Barcoding Assay. Nat. Commun. 2019, 10, 3854. [CrossRef] [PubMed]

41. Zhou, Q.; Cai, Y.; Lin, X. The Dual Character of Exosomes in Osteoarthritis: Antagonists and Therapeutic Agents. Acta Biomater. 2020, 105, 15-25. [CrossRef]

42. Álvarez-Viejo, M. Mesenchymal Stem Cells from Different Sources and Their Derived Exosomes: A Pre-Clinical Perspective. World J. Stem Cells 2020, 12, 100-109. [CrossRef]

43. Cumba Garcia, L.M.; Peterson, T.E.; Cepeda, M.A.; Johnson, A.J.; Parney, I.F. Isolation and Analysis of Plasma-Derived Exosomes in Patients With Glioma. Front. Oncol. 2019, 9, 651. [CrossRef] [PubMed]

44. Cheng, Y.; Qu, X.; Dong, Z.; Zeng, Q.; Ma, X.; Jia, Y.; Li, R.; Jiang, X.; Williams, C.; Wang, T.; et al. Comparison of Serum Exosome Isolation Methods on Co-Precipitated Free MicroRNAs. PeerJ 2020, 8, e9434. [CrossRef]

45. Gao, F.; Jiao, F.; Xia, C.; Zhao, Y.; Ying, W.; Xie, Y.; Guan, X.; Tao, M.; Zhang, Y.; Qin, W.; et al. A Novel Strategy for Facile Serum Exosome Isolation Based on Specific Interactions between Phospholipid Bilayers and $\mathrm{TiO}_{2}$. Chem. Sci. 2019, 10, 1579-1588. [CrossRef] [PubMed]

46. Street, J.M.; Koritzinsky, E.H.; Glispie, D.M.; Star, R.A.; Yuen, P.S.T. Urine Exosomes: An Emerging Trove of Biomarkers. Adv. Clin. Chem. 2017, 78, 103-122. [CrossRef]

47. He, L.; Zhu, D.; Wang, J.; Wu, X. A Highly Efficient Method for Isolating Urinary Exosomes. Int. J. Mol. Med. 2019, 43, 83-90. [CrossRef]

48. Galley, J.D.; Besner, G.E. The Therapeutic Potential of Breast Milk-Derived Extracellular Vesicles. Nutrients 2020, $12,745$. [CrossRef] 
49. Reif, S.; Elbaum Shiff, Y.; Golan-Gerstl, R. Milk-Derived Exosomes (MDEs) Have a Different Biological Effect on Normal Fetal Colon Epithelial Cells Compared to Colon Tumor Cells in a MiRNA-Dependent Manner. J. Transl. Med. 2019, 17, 325. [CrossRef]

50. Vaswani, K.; Mitchell, M.D.; Holland, O.J.; Qin Koh, Y.; Hill, R.J.; Harb, T.; Davies, P.S.W.; Peiris, H. A Method for the Isolation of Exosomes from Human and Bovine Milk. Available online: https://www.hindawi.com/journals/jnme/2019/5764740/ (accessed on 28 February 2021).

51. Pucci, M.; Taverna, S.; Reclusa, P.; Pinto, J.; Durendez Saez, E.; Jantus, E.; Maralani, M.; Zito, G.; Rolfo, C. Exosomes in Semen: Opportunities as a New Tool in Prostate Cancer Diagnosis. Transl. Cancer Res. 2017, 6, S1331-S1338. [CrossRef]

52. Madison, M.N.; Welch, J.L.; Okeoma, C.M. Isolation of Exosomes from Semen for in vitro Uptake and HIV-1 Infection Assays. Bio Protoc. 2017, 7, e2216. [CrossRef] [PubMed]

53. Cheshmi, B.; Cheshomi, H. Salivary Exosomes: Properties, Medical Applications, and Isolation Methods. Mol. Biol. Rep. 2020, 47, 6295-6307. [CrossRef]

54. Han, Y.; Jia, L.; Zheng, Y.; Li, W. Salivary Exosomes: Emerging Roles in Systemic Disease. Int. J. Biol. Sci. 2018, 14, 633-643. [CrossRef]

55. Ebert, B.; Rai, A.J. Isolation and Characterization of Amniotic Fluid-Derived Extracellular Vesicles for Biomarker Discovery. Methods Mol. Biol. 2019, 1885, 287-294. [CrossRef] [PubMed]

56. Sheller-Miller, S.; Menon, R. Isolation and characterization of human amniotic fluid-derived exosomes. Methods Enzymol. 2020, 645, 181-194.

57. Hu, Y.; Qi, C.; Liu, X.; Zhang, C.; Gao, J.; Wu, Y.; Yang, J.; Zhao, Q.; Li, J.; Wang, X.; et al. Malignant Ascites-Derived Exosomes Promote Peritoneal Tumor Cell Dissemination and Reveal a Distinct MiRNA Signature in Advanced Gastric Cancer. Cancer Lett. 2019, 457, 142-150. [CrossRef]

58. Menay, F.; Herschlik, L.; De Toro, J.; Cocozza, F.; Tsacalian, R.; Gravisaco, M.J.; Di Sciullo, M.P.; Vendrell, A.; Waldner, C.I.; Mongini, C. Exosomes Isolated from Ascites of T-Cell Lymphoma-Bearing Mice Expressing Surface CD24 and HSP-90 Induce a Tumor-Specific Immune Response. Front. Immunol. 2017, 8, 286. [CrossRef] [PubMed]

59. Akers, J.C.; Gonda, D.; Kim, R.; Carter, B.S.; Chen, C.C. Biogenesis of Extracellular Vesicles (EV): Exosomes, Microvesicles, Retrovirus-like Vesicles, and Apoptotic Bodies. J. Neurooncol. 2013, 113, 1-11. [CrossRef]

60. Spaull, R.; McPherson, B.; Gialeli, A.; Clayton, A.; Uney, J.; Heep, A.; Cordero-Llana, Ó. Exosomes Populate the Cerebrospinal Fluid of Preterm Infants with Post-Haemorrhagic Hydrocephalus. Int. J. Dev. Neurosci. 2019, 73, 59-65. [CrossRef]

61. Welton, J.L.; Loveless, S.; Stone, T.; von Ruhland, C.; Robertson, N.P.; Clayton, A. Cerebrospinal Fluid Extracellular Vesicle Enrichment for Protein Biomarker Discovery in Neurological Disease; Multiple Sclerosis. J. Extracell Vesicles 2017, 6, 1369805. [CrossRef]

62. Li, A.; Zhang, T.; Zheng, M.; Liu, Y.; Chen, Z. Exosomal Proteins as Potential Markers of Tumor Diagnosis. J. Hematol. Oncol. 2017, 10, 175. [CrossRef]

63. Xu, M.; Yang, Q.; Sun, X.; Wang, Y. Recent Advancements in the Loading and Modification of Therapeutic Exosomes. Front. Bioeng. Biotechnol. 2020, 8, 1173. [CrossRef]

64. Yang, X.-X.; Sun, C.; Wang, L.; Guo, X.-L. New Insight into Isolation, Identification Techniques and Medical Applications of Exosomes. J. Control. Release 2019, 308, 119-129. [CrossRef]

65. Yang, D.; Zhang, W.; Zhang, H.; Zhang, F.; Chen, L.; Ma, L.; Larcher, L.M.; Chen, S.; Liu, N.; Zhao, Q.; et al. Progress, Opportunity, and Perspective on Exosome Isolation-Efforts for Efficient Exosome-Based Theranostics. Theranostics 2020, 10, $3684-3707$. [CrossRef]

66. Bunggulawa, E.J.; Wang, W.; Yin, T.; Wang, N.; Durkan, C.; Wang, Y.; Wang, G. Recent Advancements in the Use of Exosomes as Drug Delivery Systems. J. Nanobiotechnol. 2018, 16, 81. [CrossRef]

67. Zhang, M.; Viennois, E.; Xu, C.; Merlin, D. Plant Derived Edible Nanoparticles as a New Therapeutic Approach against Diseases. Tissue Barriers 2016, 4, e1134415. [CrossRef]

68. Sarvarian, P.; Samadi, P.; Gholipour, E.; Shams Asenjan, K.; Hojjat-Farsangi, M.; Motavalli, R.; Motavalli Khiavi, F.; Yousefi, M. Application of Emerging Plant-Derived Nanoparticles as a Novel Approach for Nano-Drug Delivery Systems. Immunol. Invest. 2021, 1-21. [CrossRef]

69. Rome, S. Biological Properties of Plant-Derived Extracellular Vesicles. Food Funct. 2019, 10, 529-538. [CrossRef]

70. Yang, C.; Zhang, M.; Merlin, D. Advances in Plant-Derived Edible Nanoparticle-Based Lipid Nano-Drug Delivery Systems as Therapeutic Nanomedicines. J. Mater. Chem. B 2018, 6, 1312-1321. [CrossRef]

71. Xiao, J.; Feng, S.; Wang, X.; Long, K.; Luo, Y.; Wang, Y.; Ma, J.; Tang, Q.; Jin, L.; Li, X.; et al. Identification of Exosome-like Nanoparticle-Derived MicroRNAs from 11 Edible Fruits and Vegetables. PeerJ 2018, 6, e5186. [CrossRef]

72. Munir, J.; Lee, M.; Ryu, S. Exosomes in Food: Health Benefits and Clinical Relevance in Diseases. Adv. Nutr. 2020, 11, 687-696. [CrossRef] [PubMed]

73. Iravani, S.; Varma, R.S. Plant-Derived Edible Nanoparticles and MiRNAs: Emerging Frontier for Therapeutics and Targeted Drug-Delivery. ACS Sustain. Chem. Eng. 2019, 7, 8055-8069. [CrossRef]

74. Perut, F.; Roncuzzi, L.; Avnet, S.; Massa, A.; Zini, N.; Sabbadini, S.; Giampieri, F.; Mezzetti, B.; Baldini, N. Strawberry-Derived Exosome-Like Nanoparticles Prevent Oxidative Stress in Human Mesenchymal Stromal Cells. Biomolecules 2021, 11, 87. [CrossRef] 
75. Liu, B.; Lu, Y.; Chen, X.; Muthuraj, P.G.; Li, X.; Pattabiraman, M.; Zempleni, J.; Kachman, S.D.; Natarajan, S.K.; Yu, J. Protective Role of Shiitake Mushroom-Derived Exosome-Like Nanoparticles in D-Galactosamine and Lipopolysaccharide-Induced Acute Liver Injury in Mice. Nutrients 2020, 12, 477. [CrossRef]

76. Alzahrani, F.A. Melatonin Improves Therapeutic Potential of Mesenchymal Stem Cells-Derived Exosomes against Renal IschemiaReperfusion Injury in Rats. Am. J. Transl. Res. 2019, 11, 2887-2907. [PubMed]

77. Walker, S.; Busatto, S.; Pham, A.; Tian, M.; Suh, A.; Carson, K.; Quintero, A.; Lafrence, M.; Malik, H.; Santana, M.X.; et al. Extracellular Vesicle-Based Drug Delivery Systems for Cancer Treatment. Theranostics 2019, 9, 8001-8017. [CrossRef]

78. Rodrigues, P.; Melim, C.; Veiga, F.; Figueiras, A. An Overview of Exosomes in Cancer Therapy: A Small Solution to a Big Problem. Processes 2020, 8, 1561. [CrossRef]

79. Faruqu, F.N.; Xu, L.; Al-Jamal, K.T. Preparation of Exosomes for SiRNA Delivery to Cancer Cells. J. Vis. Exp. 2018, 142, e58814. [CrossRef]

80. Hajipour, H.; Farzadi, L.; Roshangar, L.; Latifi, Z.; Kahroba, H.; Shahnazi, V.; Hamdi, K.; Ghasemzadeh, A.; Fattahi, A.; Nouri, M. A Human Chorionic Gonadotropin (HCG) Delivery Platform Using Engineered Uterine Exosomes to Improve Endometrial Receptivity. Life Sci. 2021, 275, 119351. [CrossRef]

81. Warren, M.R.; Zhang, C.; Vedadghavami, A.; Bokvist, K.; Dhal, P.K.; Bajpayee, A.G. Milk Exosomes with Enhanced Mucus Penetrability for Oral Delivery of SiRNA. Biomater. Sci. 2021, 9, 4260-4277. [CrossRef] [PubMed]

82. Guo, P.; Busatto, S.; Huang, J.; Morad, G.; Moses, M.A. A Facile Magnetic Extrusion Method for Preparing Endosome-Derived Vesicles for Cancer Drug Delivery. Adv.Funct. Mater. 2021, 2008326. [CrossRef]

83. Zhou, W.; Zhou, Y.; Chen, X.; Ning, T.; Chen, H.; Guo, Q.; Zhang, Y.; Liu, P.; Zhang, Y.; Li, C.; et al. Pancreatic CancerTargeting Exosomes for Enhancing Immunotherapy and Reprogramming Tumor Microenvironment. Biomaterials 2021, 268, 120546. [CrossRef]

84. Yang, X.; Xie, B.; Peng, H.; Shi, G.; Sreenivas, B.; Guo, J.; Wang, C.; He, Y. Eradicating Intracellular MRSA via Targeted Delivery of Lysostaphin and Vancomycin with Mannose-Modified Exosomes. J. Control. Release 2021, 329, 454-467. [CrossRef] [PubMed]

85. Man, K.; Brunet, M.Y.; Jones, M.-C.; Cox, S.C. Engineered Extracellular Vesicles: Tailored-Made Nanomaterials for Medical Applications. Nanomaterilas 2020, 10, 1838. [CrossRef] [PubMed]

86. Wang, J.; Chen, D.; Ho, E.A. Challenges in the Development and Establishment of Exosome-Based Drug Delivery Systems. J. Control. Release 2021, 329, 894-906. [CrossRef] [PubMed]

87. Chinnappan, M.; Srivastava, A.; Amreddy, N.; Razaq, M.; Pareek, V.; Ahmed, R.; Mehta, M.; Peterson, J.E.; Munshi, A.; Ramesh, R. Exosomes as Drug Delivery Vehicle and Contributor of Resistance to Anticancer Drugs. Cancer Lett. 2020, 486, 18-28. [CrossRef] [PubMed]

88. Mentkowski, K.I.; Snitzer, J.D.; Rusnak, S.; Lang, J.K. Therapeutic Potential of Engineered Extracellular Vesicles. AAPS J. 2018, 20, 50. [CrossRef]

89. Salunkhe, S.; Dheeraj; Basak, M.; Chitkara, D.; Mittal, A. Surface Functionalization of Exosomes for Target-Specific Delivery and in Vivo Imaging \& Tracking: Strategies and Significance. J. Control. Release 2020, 326, 599-614. [CrossRef]

90. Tian, T.; Zhang, H.-X.; He, C.-P.; Fan, S.; Zhu, Y.-L.; Qi, C.; Huang, N.-P.; Xiao, Z.-D.; Lu, Z.-H.; Tannous, B.A.; et al. Surface Functionalized Exosomes as Targeted Drug Delivery Vehicles for Cerebral Ischemia Therapy. Biomaterials 2018, 150, 137-149. [CrossRef]

91. Xu, L.; Faruqu, F.N.; Liam-or, R.; Abed, O.A.; Li, D.; Venner, K.; Errington, R.J.; Summers, H.; Wang, J.T.-W.; Al-Jamal, K.T. Design of Experiment (DoE)-Driven in vitro and in vivo Uptake Studies of Exosomes for Pancreatic Cancer Delivery Enabled by Copper-Free Click Chemistry-Based Labelling. J. Extracell. Vesicles 2020, 9, 1779458. [CrossRef]

92. Zhang, K.-L.; Wang, Y.-J.; Sun, J.; Zhou, J.; Xing, C.; Huang, G.; Li, J.; Yang, H. Artificial Chimeric Exosomes for Anti-Phagocytosis and Targeted Cancer Therapy. Chem. Sci. 2019, 10, 1555-1561. [CrossRef]

93. Marchianò, V.; Matos, M.; Serrano-Pertierra, E.; Gutiérrez, G.; Blanco-López, M.C. Vesicles as Antibiotic Carrier: State of Art. Int. J. Pharm. 2020, 585, 119478. [CrossRef]

94. Susa, F.; Limongi, T.; Dumontel, B.; Vighetto, V.; Cauda, V. Engineered Extracellular Vesicles as a Reliable Tool in Cancer Nanomedicine. Cancers 2019, 11, 1979. [CrossRef]

95. Zhang, Y.-F.; Shi, J.-B.; Li, C. Small Extracellular Vesicle Loading Systems in Cancer Therapy: Current Status and the Way Forward. Cytotherapy 2019, 21, 1122-1136. [CrossRef]

96. Zhang, Z.; Dombroski, J.A.; King, M.R. Engineering of Exosomes to Target Cancer Metastasis. Cel. Mol. Bioeng. 2020, 13, 1-16. [CrossRef] [PubMed]

97. Cheng, G.; Li, W.; Ha, L.; Han, X.; Hao, S.; Wan, Y.; Wang, Z.; Dong, F.; Zou, X.; Mao, Y.; et al. Self-Assembly of Extracellular Vesicle-like Metal-Organic Framework Nanoparticles for Protection and Intracellular Delivery of Biofunctional Proteins. J. Am. Chem. Soc. 2018, 140, 7282-7291. [CrossRef]

98. Lu, M.; Zhao, X.; Xing, H.; Xun, Z.; Yang, T.; Cai, C.; Wang, D.; Ding, P. Liposome-Chaperoned Cell-Free Synthesis for the Design of Proteoliposomes: Implications for Therapeutic Delivery. Acta Biomater. 2018, 76, 1-20. [CrossRef] [PubMed]

99. Hood, J.L. Post Isolation Modification of Exosomes for Nanomedicine Applications. Nanomedicine 2016, 11, 1745-1756. [CrossRef] [PubMed]

100. Fu, S.; Wang, Y.; Xia, X.; Zheng, J.C. Exosome Engineering: Current Progress in Cargo Loading and Targeted Delivery. NanoImpact 2020, 20, 100261. [CrossRef] 
101. Donoso-Quezada, J.; Ayala-Mar, S.; González-Valdez, J. State-of-the-Art Exosome Loading and Functionalization Techniques for Enhanced Therapeutics: A Review. Crit. Rev. Biotechnol. 2020, 40, 804-820. [CrossRef]

102. Das, C.K.; Jena, B.C.; Banerjee, I.; Das, S.; Parekh, A.; Bhutia, S.K.; Mandal, M. Exosome as a Novel Shuttle for Delivery of Therapeutics across Biological Barriers. Mol. Pharm. 2019, 16, 24-40. [CrossRef] [PubMed]

103. Kim, H.; Kim, E.H.; Kwak, G.; Chi, S.-G.; Kim, S.H.; Yang, Y. Exosomes: Cell-Derived Nanoplatforms for the Delivery of Cancer Therapeutics. Int. J. Mol. Sci. 2021, 22, 14. [CrossRef]

104. He, R.; Jiang, Y.; Shi, Y.; Liang, J.; Zhao, L. Curcumin-Laden Exosomes Target Ischemic Brain Tissue and Alleviate Cerebral Ischemia-Reperfusion Injury by Inhibiting ROS-Mediated Mitochondrial Apoptosis. Mater. Sci. Eng. C 2020, $117,111314$. [CrossRef] [PubMed]

105. Salarpour, S.; Forootanfar, H.; Pournamdari, M.; Ahmadi-Zeidabadi, M.; Esmaeeli, M.; Pardakhty, A. Paclitaxel Incorporated Exosomes Derived from Glioblastoma Cells: Comparative Study of Two Loading Techniques. DARU J. Pharm. Sci. 2019, 27, 533-539. [CrossRef]

106. Wang, P.; Wang, H.; Huang, Q.; Peng, C.; Yao, L.; Chen, H.; Qiu, Z.; Wu, Y.; Wang, L.; Chen, W. Exosomes from M1-Polarized Macrophages Enhance Paclitaxel Antitumor Activity by Activating Macrophages-Mediated Inflammation. Theranostics 2019, 9 , 1714-1727. [CrossRef] [PubMed]

107. Schindler, C.; Collinson, A.; Matthews, C.; Pointon, A.; Jenkinson, L.; Minter, R.R.; Vaughan, T.J.; Tigue, N.J. Exosomal Delivery of Doxorubicin Enables Rapid Cell Entry and Enhanced in vitro Potency. PLoS ONE 2019, 14, e0214545. [CrossRef]

108. Tran, P.H.L.; Wang, T.; Yin, W.; Tran, T.T.D.; Nguyen, T.N.G.; Lee, B.-J.; Duan, W. Aspirin-Loaded Nanoexosomes as Cancer Therapeutics. Int. J. Pharm. 2019, 572, 118786. [CrossRef]

109. Li, Y.-J.; Wu, J.-Y.; Wang, J.-M.; Hu, X.-B.; Cai, J.-X.; Xiang, D.-X. Gemcitabine Loaded Autologous Exosomes for Effective and Safe Chemotherapy of Pancreatic Cancer. Acta Biomater. 2020, 101, 519-530. [CrossRef]

110. Yang, X.; Shi, G.; Guo, J.; Wang, C.; He, Y. Exosome-Encapsulated Antibiotic against Intracellular Infections of Methicillin-Resistant Staphylococcus Aureus. Int. J. Nanomed. 2018, 13, 8095-8104. [CrossRef]

111. Haney, M.J.; Klyachko, N.L.; Zhao, Y.; Gupta, R.; Plotnikova, E.G.; He, Z.; Patel, T.; Piroyan, A.; Sokolsky, M.; Kabanov, A.V.; et al. Exosomes as Drug Delivery Vehicles for Parkinson's Disease Therapy. J. Control. Release 2015, 207, 18-30. [CrossRef]

112. Kim, G.; Lee, Y.; Ha, J.; Han, S.; Lee, M. Engineering Exosomes for Pulmonary Delivery of Peptides and Drugs to Inflammatory Lung Cells by Inhalation. J. Control. Release 2021, 330, 684-695. [CrossRef] [PubMed]

113. Tran, P.H.L.; Wang, T.; Yin, W.; Tran, T.T.D.; Barua, H.T.; Zhang, Y.; Midge, S.B.; Nguyen, T.N.G.; Lee, B.-J.; Duan, W. Development of a Nanoamorphous Exosomal Delivery System as an Effective Biological Platform for Improved Encapsulation of Hydrophobic Drugs. Int. J. Pharm. 2019, 566, 697-707. [CrossRef]

114. Wei, H.; Chen, J.; Wang, S.; Fu, F.; Zhu, X.; Wu, C.; Liu, Z.; Zhong, G.; Lin, J. A Nanodrug Consisting Of Doxorubicin And Exosome Derived From Mesenchymal Stem Cells For Osteosarcoma Treatment In Vitro. Int. J. Nanomed. 2019, 14, 8603-8610. [CrossRef]

115. Lin, Q.; Qu, M.; Zhou, B.; Patra, H.K.; Sun, Z.; Luo, Q.; Yang, W.; Wu, Y.; Zhang, Y.; Li, L.; et al. Exosome-like Nanoplatform Modified with Targeting Ligand Improves Anti-Cancer and Anti-Inflammation Effects of Imperialine. J. Control. Release 2019, 311, 104-116. [CrossRef]

116. Aqil, F.; Munagala, R.; Jeyabalan, J.; Agrawal, A.K.; Kyakulaga, A.-H.; Wilcher, S.A.; Gupta, R.C. Milk Exosomes-Natural Nanoparticles for SiRNA Delivery. Cancer Lett. 2019, 449, 186-195. [CrossRef] [PubMed]

117. Zhao, L.; Gu, C.; Gan, Y.; Shao, L.; Chen, H.; Zhu, H. Exosome-Mediated SiRNA Delivery to Suppress Postoperative Breast Cancer Metastasis. J. Control. Release 2020, 318, 1-15. [CrossRef]

118. Giassafaki, L.-P.N.; Siqueira, S.; Panteris, E.; Psatha, K.; Chatzopoulou, F.; Aivaliotis, M.; Tzimagiorgis, G.; Müllertz, A.; Fatouros, D.G.; Vizirianakis, I.S. Towards Analyzing the Potential of Exosomes to Deliver MicroRNA Therapeutics. J. Cell. Physiol. 2021, 236, 1529-1544. [CrossRef]

119. Sancho-Albero, M.; Encabo-Berzosa, M.D.M.; Beltrán-Visiedo, M.; Fernández-Messina, L.; Sebastián, V.; Sánchez-Madrid, F.; Arruebo, M.; Santamaría, J.; Martín-Duque, P. Efficient Encapsulation of Theranostic Nanoparticles in Cell-Derived Exosomes: Leveraging the Exosomal Biogenesis Pathway to Obtain Hollow Gold Nanoparticle-Hybrids. Nanoscale 2019, 11, 18825-18836. [CrossRef]

120. Zhang, M.; Xiao, B.; Wang, H.; Han, M.K.; Zhang, Z.; Viennois, E.; Xu, C.; Merlin, D. Edible Ginger-Derived Nano-Lipids Loaded with Doxorubicin as a Novel Drug-Delivery Approach for Colon Cancer Therapy. Mol. Ther. 2016, 24, 1783-1796. [CrossRef] [PubMed]

121. Zhang, M.; Viennois, E.; Prasad, M.; Zhang, Y.; Wang, L.; Zhang, Z.; Han, M.K.; Xiao, B.; Xu, C.; Srinivasan, S.; et al. Edible Ginger-Derived Nanoparticles: A Novel Therapeutic Approach for the Prevention and Treatment of Inflammatory Bowel Disease and Colitis-Associated Cancer. Biomaterials 2016, 101, 321-340. [CrossRef] [PubMed]

122. Chen, X.; Zhou, Y.; Yu, J. Exosome-like Nanoparticles from Ginger Rhizomes Inhibited NLRP3 Inflammasome Activation. Mol. Pharm. 2019, 16, 2690-2699. [CrossRef] [PubMed]

123. Wang, Q.; Ren, Y.; Mu, J.; Egilmez, N.K.; Zhuang, X.; Deng, Z.; Zhang, L.; Yan, J.; Miller, D.; Zhang, H.-G. Grapefruit-Derived Nanovectors Use an Activated Leukocyte Trafficking Pathway to Deliver Therapeutic Agents to Inflammatory Tumor Sites. Cancer Res. 2015, 75, 2520-2529. [CrossRef] [PubMed] 
124. Deng, Z.; Rong, Y.; Teng, Y.; Mu, J.; Zhuang, X.; Tseng, M.; Samykutty, A.; Zhang, L.; Yan, J.; Miller, D.; et al. Broccoli-Derived Nanoparticle Inhibits Mouse Colitis by Activating Dendritic Cell AMP-Activated Protein Kinase. Mol. Ther. 2017, 25, 1641-1654. [CrossRef]

125. Karaosmanoğlu, O. Investigation of the Cytotoxicity of Fig, Lemon, Olive, and Turnip Exosomes on MCF-7 Cells. KSU J. Agric Na. 2019, 22, 382-387. [CrossRef]

126. Fujita, D.; Arai, T.; Komori, H.; Shirasaki, Y.; Wakayama, T.; Nakanishi, T.; Tamai, I. Apple-Derived Nanoparticles Modulate Expression of Organic-Anion-Transporting Polypeptide (OATP) 2 B1 in Caco-2 Cells. Mol. Pharm. 2018, 15, 5772-5780. [CrossRef]

127. Chung, I.-M.; Rajakumar, G.; Venkidasamy, B.; Subramanian, U.; Thiruvengadam, M. Exosomes: Current Use and Future Applications. Clin. Chim. Acta 2020, 500, 226-232. [CrossRef] [PubMed]

128. Kalluri, R.; LeBleu, V.S. The Biology, Function, and Biomedical Applications of Exosomes. Science 2020, 367, eaau6977. [CrossRef]

129. Bryl, R.; Borowiec, B.; Siroma, R.S.; Pinto, N.; Melo, M.A.; Shibli, J.A.; Dyszkiewicz-Konwińska, M. Current Application of Exosomes in Medicine. Med. J. Cell Biol. 2020, 8, 101-111. [CrossRef]

130. Jiang, L.; Gu, Y.; Du, Y.; Liu, J. Exosomes: Diagnostic Biomarkers and Therapeutic Delivery Vehicles for Cancer. Mol. Pharm. 2019, 16, 3333-3349. [CrossRef]

131. Inamdar, S.; Nitiyanandan, R.; Rege, K. Emerging Applications of Exosomes in Cancer Therapeutics and Diagnostics. Bioeng. Transl. Med. 2017, 2, 70-80. [CrossRef] [PubMed]

132. Otero-Ortega, L.; Laso-García, F.; Gómez-de Frutos, M.; Fuentes, B.; Diekhorst, L.; Díez-Tejedor, E.; Gutiérrez-Fernández, M. Role of Exosomes as a Treatment and Potential Biomarker for Stroke. Transl. Stroke Res. 2019, 10, 241-249. [CrossRef] [PubMed]

133. Esfandyari, S.; Elkafas, H.; Chugh, R.M.; Park, H.; Navarro, A.; Al-Hendy, A. Exosomes as Biomarkers for Female Reproductive Diseases Diagnosis and Therapy. Int. J. Mol. Sci. 2021, 22, 2165. [CrossRef]

134. Raghav, A.; Khan, Z.A.; Upadhayay, V.K.; Tripathi, P.; Gautam, K.A.; Mishra, B.K.; Ahmad, J.; Jeong, G.-B. Mesenchymal Stem Cell-Derived Exosomes Exhibit Promising Potential for Treating SARS-CoV-2-Infected Patients. Cells 2021, 10, 587. [CrossRef]

135. Soares Martins, T.; Trindade, D.; Vaz, M.; Campelo, I.; Almeida, M.; Trigo, G.; da Cruz E Silva, O.A.B.; Henriques, A.G. Diagnostic and Therapeutic Potential of Exosomes in Alzheimer's Disease. J. Neurochem. 2021, 156, 162-181. [CrossRef]

136. Jalalian, S.H.; Ramezani, M.; Jalalian, S.A.; Abnous, K.; Taghdisi, S.M. Exosomes, New Biomarkers in Early Cancer Detection. Anal. Biochem. 2019, 571, 1-13. [CrossRef]

137. Luo, S.; Du, L.; Cui, Y. Potential Therapeutic Applications and Developments of Exosomes in Parkinson's Disease. Mol. Pharm. 2020, 17, 1447-1457. [CrossRef]

138. Jia, L.; Zhu, M.; Kong, C.; Pang, Y.; Zhang, H.; Qiu, Q.; Wei, C.; Tang, Y.; Wang, Q.; Li, Y.; et al. Blood Neuro-Exosomal Synaptic Proteins Predict Alzheimer's Disease at the Asymptomatic Stage. Alzheimers Dement. 2021, 17, 49-60. [CrossRef] [PubMed]

139. Zhang, M.; Zang, X.; Wang, M.; Li, Z.; Qiao, M.; Hu, H.; Chen, D. Exosome-Based Nanocarriers as Bio-Inspired and Versatile Vehicles for Drug Delivery: Recent Advances and Challenges. J. Mater. Chem. B 2019, 7, 2421-2433. [CrossRef] [PubMed]

140. Samuel, M.; Gabrielsson, S. Personalized Medicine and Back-Allogeneic Exosomes for Cancer Immunotherapy. J. Intern. Med. 2021, 289, 138-146. [CrossRef]

141. Sinha, D.; Roy, S.; Saha, P.; Chatterjee, N.; Bishayee, A. Trends in Research on Exosomes in Cancer Progression and Anticancer Therapy. Cancers 2021, 13, 326. [CrossRef]

142. Tan, A.; De La Peña, H.; Seifalian, A.M. The Application of Exosomes as a Nanoscale Cancer Vaccine. Int. J. Nanomed. 2010, 5 , 889-900. [CrossRef]

143. Naseri, M.; Bozorgmehr, M.; Zöller, M.; Ranaei Pirmardan, E.; Madjd, Z. Tumor-Derived Exosomes: The next Generation of Promising Cell-Free Vaccines in Cancer Immunotherapy. Oncoimmunology 2020, 9, 1779991. [CrossRef] [PubMed]

144. Larabi, A.; Barnich, N.; Nguyen, H.T.T. Emerging Role of Exosomes in Diagnosis and Treatment of Infectious and Inflammatory Bowel Diseases. Cells 2020, 9, 1111. [CrossRef] [PubMed]

145. Sabanovic, B.; Piva, F.; Cecati, M.; Giulietti, M. Promising Extracellular Vesicle-Based Vaccines against Viruses, Including SARS-CoV-2. Biology 2021, 10, 94. [CrossRef] [PubMed]

146. Lee, B.-C.; Kang, I.; Yu, K.-R. Therapeutic Features and Updated Clinical Trials of Mesenchymal Stem Cell (MSC)-Derived Exosomes. J. Clin. Med. 2021, 10, 711. [CrossRef]

147. Rezaie, J.; Ajezi, S.; Avci, Ç.B.; Karimipour, M.; Geranmayeh, M.H.; Nourazarian, A.; Sokullu, E.; Rezabakhsh, A.; Rahbarghazi, R. Exosomes and Their Application in Biomedical Field: Difficulties and Advantages. Mol. Neurobiol. 2018, 55, 3372-3393. [CrossRef]

148. Jiang, X.-C.; Gao, J.-Q. Exosomes as Novel Bio-Carriers for Gene and Drug Delivery. Int. J. Pharm. 2017, 521, 167-175. [CrossRef] [PubMed]

149. Mathiyalagan, P.; Sahoo, S. Exosomes-Based Gene Therapy for MicroRNA Delivery. Methods Mol. Biol. 2017, 1521, 139-152. [CrossRef]

150. Li, Z.; Zhao, P.; Zhang, Y.; Wang, J.; Wang, C.; Liu, Y.; Yang, G.; Yuan, L. Exosome-Based Ldlr Gene Therapy for Familial Hypercholesterolemia in a Mouse Model. Theranostics 2021, 11, 2953-2965. [CrossRef]

151. Vakhshiteh, F.; Rahmani, S.; Ostad, S.N.; Madjd, Z.; Dinarvand, R.; Atyabi, F. Exosomes Derived from MiR-34a-Overexpressing Mesenchymal Stem Cells Inhibit in vitro Tumor Growth: A New Approach for Drug Delivery. Life Sci. 2021, $266,118871$. [CrossRef] [PubMed]

152. Liu, Y.; Ma, Y.; Zhang, J.; Yuan, Y.; Wang, J. Exosomes: A Novel Therapeutic Agent for Cartilage and Bone Tissue Regeneration. Dose Response 2019, 17. [CrossRef] 
153. Sun, B.; Peng, J.; Wang, S.; Liu, X.; Zhang, K.; Zhang, Z.; Wang, C.; Jing, X.; Zhou, C.; Wang, Y. Applications of Stem Cell-Derived Exosomes in Tissue Engineering and Neurological Diseases. Rev. Neurosci. 2018, 29, 531-546. [CrossRef]

154. Al-Sowayan, B.; Alammari, F.; Alshareeda, A. Preparing the Bone Tissue Regeneration Ground by Exosomes: From Diagnosis to Therapy. Molecules 2020, 25, 4205. [CrossRef] [PubMed]

155. Cooper, L.F.; Ravindran, S.; Huang, C.-C.; Kang, M. A Role for Exosomes in Craniofacial Tissue Engineering and Regeneration. Front. Physiol. 2020, 10, 1569. [CrossRef]

156. Li, W.; Liu, Y.; Zhang, P.; Tang, Y.; Zhou, M.; Jiang, W.; Zhang, X.; Wu, G.; Zhou, Y. Tissue-Engineered Bone Immobilized with Human Adipose Stem Cells-Derived Exosomes Promotes Bone Regeneration. ACS Appl. Mater. Interfaces 2018, 10, 5240-5254. [CrossRef]

157. Gutierrez-Millan, C.; Díaz, C.C.; Lanao, J.M.; Colino, C.I. Advances in Exosomes-Based Drug Delivery Systems. Macromol. Biosci. 2021, 21, 2000269. [CrossRef] [PubMed]

158. Liao, W.; Du, Y.; Zhang, C.; Pan, F.; Yao, Y.; Zhang, T.; Peng, Q. Exosomes: The next Generation of Endogenous Nanomaterials for Advanced Drug Delivery and Therapy. Acta Biomater. 2019, 86, 1-14. [CrossRef] [PubMed]

159. Zhang, Y.; Liu, Y.; Liu, H.; Tang, W.H. Exosomes: Biogenesis, Biologic Function and Clinical Potential. Cell Biosci. 2019, 9, 19. [CrossRef]

160. Zheng, Y.; Hasan, A.; Nejadi Babadaei, M.M.; Behzadi, E.; Nouri, M.; Sharifi, M.; Falahati, M. Exosomes: Multiple-Targeted Multifunctional Biological Nanoparticles in the Diagnosis, Drug Delivery, and Imaging of Cancer Cells. Biomed. Pharmacother. 2020, 129, 110442. [CrossRef] [PubMed]

161. Wang, H.; Sui, H.; Zheng, Y.; Jiang, Y.; Shi, Y.; Liang, J.; Zhao, L. Curcumin-Primed Exosomes Potently Ameliorate Cognitive Function in AD Mice by Inhibiting Hyperphosphorylation of the Tau Protein through the AKT/GSK-3 $\beta$ Pathway. Nanoscale 2019, 11, 7481-7496. [CrossRef] [PubMed]

162. Mughees, M.; Kumar, K.; Wajid, S. Exosome Vesicle as a Nano-Therapeutic Carrier for Breast Cancer. J. Drug Target. 2021, 29, 121-130. [CrossRef]

163. Zhao, X.; Wu, D.; Ma, X.; Wang, J.; Hou, W.; Zhang, W. Exosomes as Drug Carriers for Cancer Therapy and Challenges Regarding Exosome Uptake. Biomed. Pharmacother. 2020, 128, 110237. [CrossRef] [PubMed]

164. Mostafazadeh, M.; Samadi, N.; Kahroba, H.; Baradaran, B.; Haiaty, S.; Nouri, M. Potential Roles and Prognostic Significance of Exosomes in Cancer Drug Resistance. Cell Biosci. 2021, 11, 1. [CrossRef]

165. Li, S.; Wu, Y.; Ding, F.; Yang, J.; Li, J.; Gao, X.; Zhang, C.; Feng, J. Engineering Macrophage-Derived Exosomes for Targeted Chemotherapy of Triple-Negative Breast Cancer. Nanoscale 2020, 12, 10854-10862. [CrossRef]

166. Gangadaran, P.; Ahn, B.-C. Extracellular Vesicle- and Extracellular Vesicle Mimetics-Based Drug Delivery Systems: New Perspectives, Challenges, and Clinical Developments. Pharmaceutics 2020, 12, 442. [CrossRef] [PubMed]

167. Jan, A.T.; Rahman, S.; Badierah, R.; Lee, E.J.; Mattar, E.H.; Redwan, E.M.; Choi, I. Expedition into Exosome Biology: A Perspective of Progress from Discovery to Therapeutic Development. Cancers 2021, 13, 1157. [CrossRef]

168. Rahmati, S.; Shojaei, F.; Shojaeian, A.; Rezakhani, L.; Dehkordi, M.B. An Overview of Current Knowledge in Biological Functions and Potential Theragnostic Applications of Exosomes. Chem. Phys. Lipids 2020, 226, 104836. [CrossRef]

169. Elliott, R.O.; He, M. Unlocking the Power of Exosomes for Crossing Biological Barriers in Drug Delivery. Pharmaceutics 2021, 13, 122. [CrossRef] [PubMed]

170. Song, Y.; Kim, Y.; Ha, S.; Sheller-Miller, S.; Yoo, J.; Choi, C.; Park, C.H. The Emerging Role of Exosomes as Novel Therapeutics: Biology, Technologies, Clinical Applications, and the Next. Am. J. Reprod. Immunol. 2021, 85, e13329. [CrossRef]

171. Liu, Y.; Wang, M.; Liang, Y.; Wang, C.; Naruse, K.; Takahashi, K. Treatment of Oxidative Stress with Exosomes in Myocardial Ischemia. Int. J. Mol. Sci. 2021, 22, 1729. [CrossRef] [PubMed]

172. Patil, S.M.; Sawant, S.S.; Kunda, N.K. Exosomes as Drug Delivery Systems: A Brief Overview and Progress Update. Eur. J. Pharm. Biopharm. 2020, 154, 259-269. [CrossRef]

173. Ortega, A.; Martinez-Arroyo, O.; Forner, M.J.; Cortes, R. Exosomes as Drug Delivery Systems: Endogenous Nanovehicles for Treatment of Systemic Lupus Erythematosus. Pharmaceutics 2020, 13, 3. [CrossRef]

174. Qu, M.; Lin, Q.; Huang, L.; Fu, Y.; Wang, L.; He, S.; Fu, Y.; Yang, S.; Zhang, Z.; Zhang, L.; et al. Dopamine-Loaded Blood Exosomes Targeted to Brain for Better Treatment of Parkinson's Disease. J. Control. Release 2018, 287, 156-166. [CrossRef]

175. Cho, B.S.; Kim, J.O.; Ha, D.H.; Yi, Y.W. Exosomes Derived from Human Adipose Tissue-Derived Mesenchymal Stem Cells Alleviate Atopic Dermatitis. Stem Cell Res. Ther. 2018, 9, 187. [CrossRef]

176. Balachandran, B.; Yuana, Y. Extracellular Vesicles-Based Drug Delivery System for Cancer Treatment. Cogent Med. 2019, 6, 1635806. [CrossRef]

177. Agrawal, A.K.; Aqil, F.; Jeyabalan, J.; Spencer, W.A.; Beck, J.; Gachuki, B.W.; Alhakeem, S.S.; Oben, K.; Munagala, R.; Bondada, S.; et al. Milk-Derived Exosomes for Oral Delivery of Paclitaxel. Nanomed. Nanotechnol. Biol. Med. 2017, 13, 1627-1636. [CrossRef] [PubMed]

178. Aqil, F.; Jeyabalan, J.; Agrawal, A.K.; Kyakulaga, A.-H.; Munagala, R.; Parker, L.; Gupta, R.C. Exosomal Delivery of Berry Anthocyanidins for the Management of Ovarian Cancer. Food Funct. 2017, 8, 4100-4107. [CrossRef] [PubMed]

179. Perets, N.; Hertz, S.; London, M.; Offen, D. Intranasal Administration of Exosomes Derived from Mesenchymal Stem Cells Ameliorates Autistic-like Behaviors of BTBR Mice. Mol. Autism 2018, 9, 57. [CrossRef] 
180. Thomi, G.; Joerger-Messerli, M.; Haesler, V.; Muri, L.; Surbek, D.; Schoeberlein, A. Intranasally Administered Exosomes from Umbilical Cord Stem Cells Have Preventive Neuroprotective Effects and Contribute to Functional Recovery after Perinatal Brain Injury. Cells 2019, 8, 855. [CrossRef]

181. Yu, G.; Jung, H.; Kang, Y.Y.; Mok, H. Comparative Evaluation of Cell- and Serum-Derived Exosomes to Deliver Immune Stimulators to Lymph Nodes. Biomaterials 2018, 162, 71-81. [CrossRef]

182. Hong, Y.; Nam, G.-H.; Koh, E.; Jeon, S.; Kim, G.B.; Jeong, C.; Kim, D.-H.; Yang, Y.; Kim, I.-S. Exosome as a Vehicle for Delivery of Membrane Protein Therapeutics, PH20, for Enhanced Tumor Penetration and Antitumor Efficacy. Adv. Funct. Mater. 2018, 28, 1703074. [CrossRef]

183. Morishita, M.; Takahashi, Y.; Matsumoto, A.; Nishikawa, M.; Takakura, Y. Exosome-Based Tumor Antigens-Adjuvant Co-Delivery Utilizing Genetically Engineered Tumor Cell-Derived Exosomes with Immunostimulatory CpG DNA. Biomaterials 2016, 111, 55-65. [CrossRef]

184. Zhou, X.; Li, Z.; Sun, W.; Yang, G.; Xing, C.; Yuan, L. Delivery Efficacy Differences of Intravenous and Intraperitoneal Injection of Exosomes: Perspectives from Tracking Dye Labeled and MiRNA Encapsulated Exosomes. Curr. Drug Deliv. 2020, 17, 186-194. [CrossRef]

185. Bonafede, R.; Turano, E.; Scambi, I.; Busato, A.; Bontempi, P.; Virla, F.; Schiaffino, L.; Marzola, P.; Bonetti, B.; Mariotti, R. ASC-Exosomes Ameliorate the Disease Progression in SOD1(G93A) Murine Model Underlining Their Potential Therapeutic Use in Human ALS. Int. J. Mol. Sci. 2020, 21, 3651. [CrossRef]

186. del Pozo-Acebo, L.; López de las Hazas, M.-C.; Tomé-Carneiro, J.; Gil-Cabrerizo, P.; San-Cristobal, R.; Busto, R.; García-Ruiz, A.; Dávalos, A. Bovine Milk-Derived Exosomes as a Drug Delivery Vehicle for MiRNA-Based Therapy. Int. J. Mol. Sci. 2021, $22,1105$. [CrossRef] [PubMed]

187. Aqil, F.; Munagala, R.; Jeyabalan, J.; Agrawal, A.K.; Gupta, R. Exosomes for the Enhanced Tissue Bioavailability and Efficacy of Curcumin. AAPS J. 2017, 19, 1691-1702. [CrossRef] [PubMed]

188. Choi, E.S.; Song, J.; Kang, Y.Y.; Mok, H. Mannose-Modified Serum Exosomes for the Elevated Uptake to Murine Dendritic Cells and Lymphatic Accumulation. Macromol. Biosci. 2019, 19, 1900042. [CrossRef] [PubMed]

189. Milano, G.; Biemmi, V.; Lazzarini, E.; Balbi, C.; Ciullo, A.; Bolis, S.; Ameri, P.; Di Silvestre, D.; Mauri, P.; Barile, L.; et al. Intravenous Administration of Cardiac Progenitor Cell-Derived Exosomes Protects against Doxorubicin/Trastuzumab-Induced Cardiac Toxicity. Cardiovasc. Res. 2020, 116, 383-392. [CrossRef]

190. Popowski, K.; Lutz, H.; Hu, S.; George, A.; Dinh, P.-U.; Cheng, K. Exosome Therapeutics for Lung Regenerative Medicine. J. Extracell Vesicles 2020, 9, 1785161. [CrossRef]

191. Saleh, A.F.; Lázaro-Ibáñez, E.; Forsgard, M.A.-M.; Shatnyeva, O.; Osteikoetxea, X.; Karlsson, F.; Heath, N.; Ingelsten, M.; Rose, J.; Harris, J.; et al. Extracellular Vesicles Induce Minimal Hepatotoxicity and Immunogenicity. Nanoscale 2019, 11, 6990-7001. [CrossRef]

192. Zhu, X.; Badawi, M.; Pomeroy, S.; Sutaria, D.S.; Xie, Z.; Baek, A.; Jiang, J.; Elgamal, O.A.; Mo, X.; Perle, K.L.; et al. Comprehensive Toxicity and Immunogenicity Studies Reveal Minimal Effects in Mice Following Sustained Dosing of Extracellular Vesicles Derived from HEK293T Cells. J. Extracell Vesicles 2017, 6, 1324730. [CrossRef] [PubMed]

193. Aegle Therapeutics. Available online: http:/ /www.aegletherapeutics.com/index.html (accessed on 17 March 2021).

194. Aethlon Medical, Inc. Available online: https:/ / www.aethlonmedical.com (accessed on 18 March 2021).

195. Anjarium Biosciences. Available online: http:/ / www.anjarium.com/ (accessed on 18 March 2021).

196. Aruna Bio. Available online: https:/ / www.arunabio.com/ (accessed on 18 March 2021).

197. Capricor Therapeutics. Available online: https:// capricor.com/ (accessed on 18 March 2021).

198. Ciloa, Inspired by Exosomes. Available online: https:/ / www.ciloa.fr/ (accessed on 18 March 2021).

199. Clara Biotech. Available online: https:/ / www.clarabio.tech (accessed on 18 March 2021).

200. Codiak Biosciences. Available online: https:/ /www.codiakbio.com/ (accessed on 18 March 2021).

201. Direct Biologics. Available online: https:/ / directbiologics.com/ (accessed on 18 March 2021).

202. Transformative Exosome Therapeutics. Available online: https://www.evoxtherapeutics.com (accessed on 18 March 2021).

203. EV Therapeutics-Extracellular Vesicle-Based Immunotherapy. Available online: https://www.evtherapeutics.com/ (accessed on 18 March 2021).

204. Exocelbio. Available online: https:/ / www.exocelbio.com/ (accessed on 18 March 2021).

205. ExoCoBio. Available online: http://www.exocobio.com/default/eng/index.php (accessed on 18 March 2021).

206. Exopharm. Available online: https:/ / exopharm.com/ (accessed on 18 March 2021).

207. ExosomeDx: Exosome Based Liquid Biopsies for Prostate Cancer. Available online: https://www.exosomedx.com/ (accessed on 18 March 2021).

208. Exosome Sciences. Available online: https:/ /www.exosomesciences.com (accessed on 18 March 2021).

209. Exosomics SpA. Available online: https://www.toscanalifesciences.org/en/stories/in-search-of-gained-time/exosomics-siena/ (accessed on 18 March 2021).

210. Exogenus Therapeutics. Available online: https://www.exogenus-t.com/ (accessed on 18 March 2021).

211. ILIAS Biologics Inc. Available online: http:/ / www.iliasbio.com/ (accessed on 18 March 2021).

212. Kimera Labs. Available online: https:/ / kimeralabs.com/ (accessed on 18 March 2021).

213. OmniSpirant Exosome Gene Therapy. Available online: https://www.omnispirant.com (accessed on 18 March 2021). 
214. ReNeuron. Available online: http:/ / www.reneuron.com/ (accessed on 18 March 2021).

215. Stem Cell Medicine Ltd. Available online: http:/ / www.stemcell-medicine.com/ (accessed on 18 March 2021).

216. Tavec Pharmaceuticals. Engineering Nature's Own Delivery Vehicle for Powerful Anti-Cancer Therapy. Available online: http:/ / tavecpharma.com/ (accessed on 18 March 2021).

217. XOStem. Available online: https://www.xostem.com/ (accessed on 18 March 2021). 